\title{
The Impact of Work Spirituality and Perceived Organizational Support on Innovative Work Behavior: Explaining the Mediating Role of Member-Organization Compatibility
}

Hamid Rezaei ${ }^{1}$ Assistant Professor of Management, Higher Education Institution of Pardisan, Fereydunkenar, Iran (Corresponding Author).

Mahsa Zamani ${ }^{2}$ Member Faculty, Department of Educational Sciences Sama, Azadshahr Branch, Islamic Azad University, Azadshahr, Iran.

\begin{abstract}
Nowadays, innovation is the basis of development and survival of social systems; however, materializing it calls for innovative work behavior. The present study intends to investigate into this issue. In order to collect data, 123 employees were selected from among the personnel of Golestan Province Civil Registration Organization. Results of structural equations modeling show that work spirituality and perceived organizational support have positive and significant effect both on member-organization Compatibility and innovative work Behavior. Besides, member-organization compatibility positively and significantly affects innovative work behavior. Moreover, the mediating role of member-organization compatibility in the relation between work spirituality and perceived organizational support, on the one side, and innovative work behavior, on the other, is confirmed. A number of applied suggestions are finally presented.
\end{abstract}

Keywords: Work Spirituality, Perceived Organizational Support, Innovative Work Behavior, Member-organization Compatibility, Golestan Province Civil Registration Organization. 
عنوان مقاله: تاثير معنويت كارى و حمايت سازمانى ادراكشده بر رفتار كارى نوآورانه: با تبانيت سبين نقش ميانجى تناسب فرد ـ سازمان

$$
\text { حميد رضايى - م-مهسا زمانى' }
$$

مقاله يزوهشى

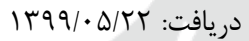

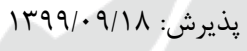

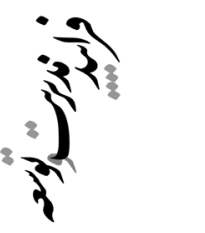

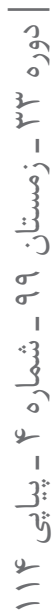

\section{جكکبه:}

امروزه نوآورى عامل اساس توسعه و ماندًارى سيستمهاى اجتماعى است و دستيابى به آن،

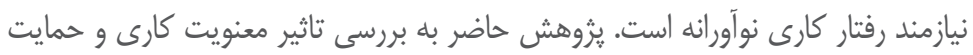

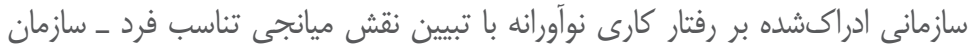

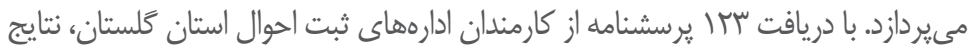

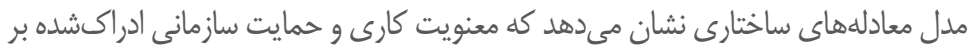

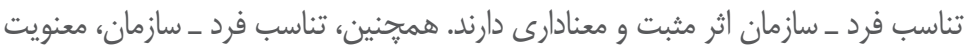

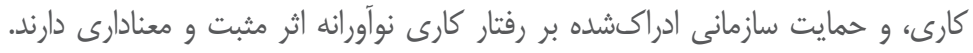

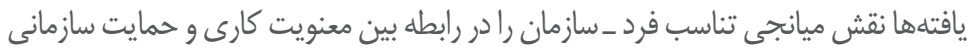

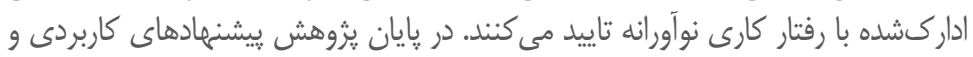

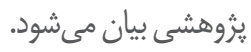

كليلوازهها: معنويت كارى، حمايت سازمانى ادراككشده، رفتار كارى نو آورانه، تناسب فرد ـسازمان، ثبت احو ال استان كلستان

1. استاديار گروه مديريت، مو سسه آموزش عالى يرديسان، فريدونكنار، ايران (نويسنده مسئول). r.rezaei99@heip.ac.ir r. مربى گروه علوم تربيتى سما، واحد آزادشهر، دانشخاه آزاد اسلامى، آزادشهر، ايران. 


\section{مقدمه}

سازمان ثبت احوال كشور نقش ويثه و موثرى در توليد آمارهاى جمعيتى و ياسداشت خدمات هويتى ايرانيان دارد. اين نقشهاى ويزه از جايگاه موثر سازمان ثبت احوال در توسعه و برنامهريزى جامعه حكايت دارد. از اينرو، اين سازمان نيازمند رفتارهاى كارى نوآورانه است (بادينى، سوسار). روشهاى گوناگونى در راه رسيدن به نرخ متناسب نوآورى با توجه به هرخه حيات سازمانها و ديكر عوامل محيطى و صنعتى وجود دارد كه يكى از آنها توجه به نيروى انسانى به عنوان ارزشمندترين

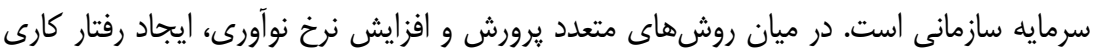

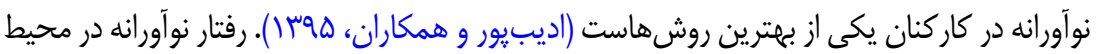
كار، رفتار يييجيدهاى است كه شامل سه زمينةُ توليد، ترويج، و ييادهسازى ايده است. توليد ايده، به

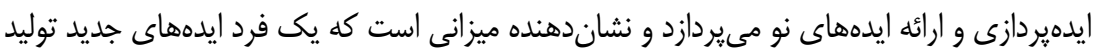
مى كند. ترويج ايده به تلاش افراد براى جلب يشتيبانى و تعهد ديگران در يِادهسازى ايدههاى جديد

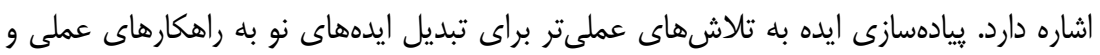

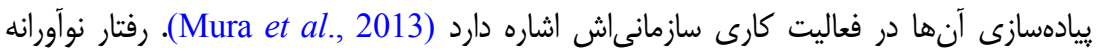

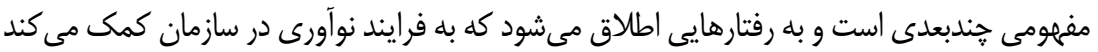

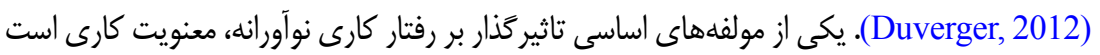
(Pandey et al., 2019) (معنويت در كار از اهميت ويزهاى برخوردار است و نقش اساسى در تحقق

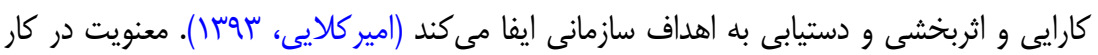
نيرويى الرامبخش و برانخيزاننده براى جستجوى مداوم هدف و معنا در زندگى كارى، درك عميق از ارزش كار، زندگى، يهناورى عالم هستى، موجودات محيط طبيعى و نظام باور شخصى است (ضيايى

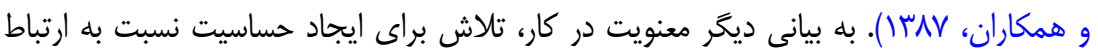
فرافردى، درونفردى، ميانفردى، و برونفردى در زندگى كارى به منظور بالندگى شخصى در رسيدن به تعالى انسانى و الرهى است (عابدى جعفرى و رستخار، عمى1). امروزه، متغيرهاى گوناگونى در سطح سازمان مىتوانتد يِامدها و نتايج كارى كاركنان هر سازمانى را از خود متاثر سازند كه حمايت سازمانى ادراكشده، يكى از متغيرهاى اثرگذار بر مان

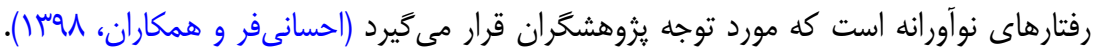


منظور از حمايت سازمانى، احساس و باورهاى تعميميافته افراد در اين راستاست كه سازمان نسبت

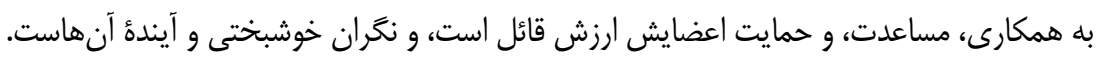

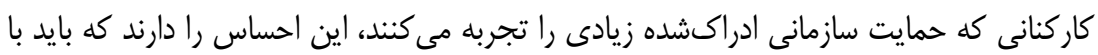

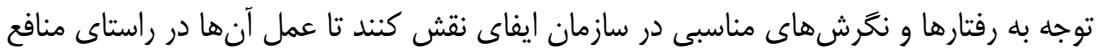
سازمان باشد و بدين وسيله حمايت سازمان را جبران كنند (عريضى و كَليرور، •وسجار). يزوهشكَران در دهلهاى اخير، به صورت نظرى و صاحبان كسبوكار در عمل به دنبال كار كنانى

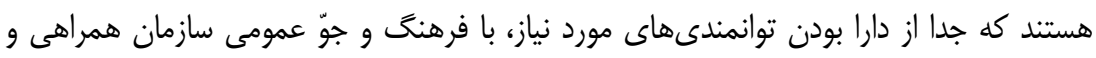

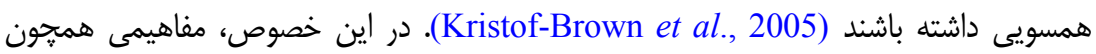
تناسب فردـسازمان مورد توجه است. تناسب فردسازمان به تطابق ميان خصوصيات فردى و

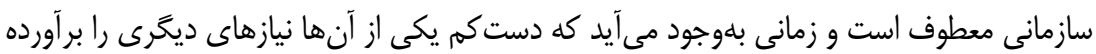

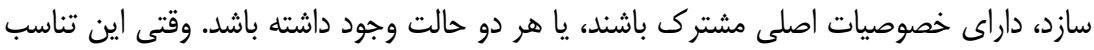

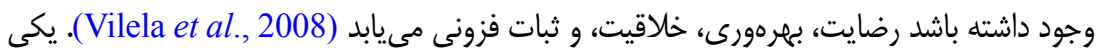

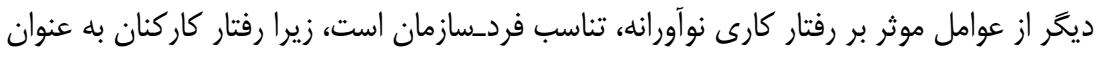

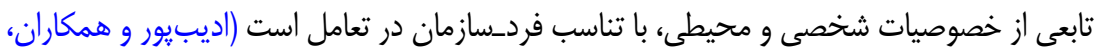

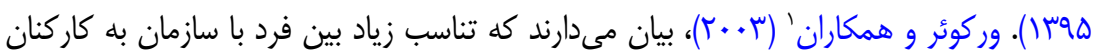

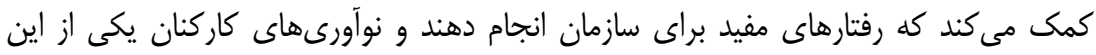

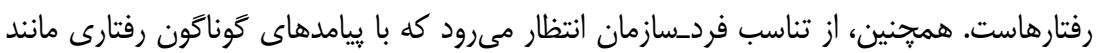
معنويت كارى و حمايت سازمانى ادراكشده در ارتباط باشد (شيرى و همكاران، هوسجان).

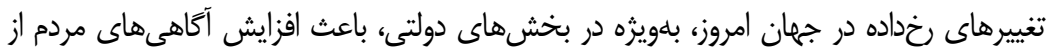

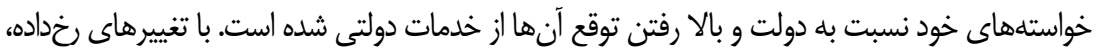

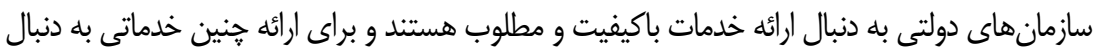
راهكارهايى براى استفاده بهينه از منابع انسانى خود هستند (Taheri Goodarzi \& Norouzi, 2019).

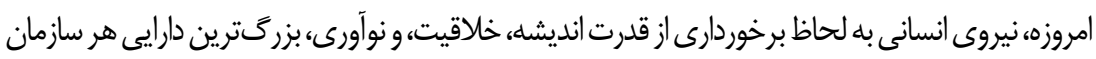

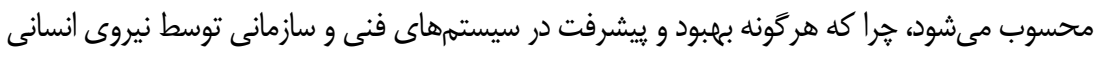

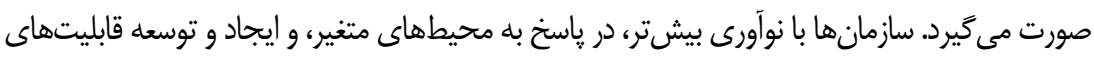

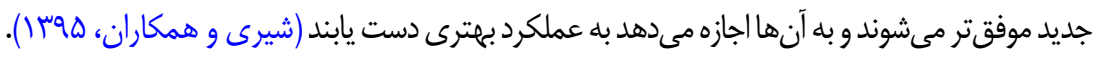

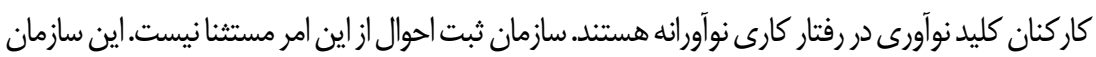

1. Verquer et al. 
به دليل گَستردگى وظايف قانونى و ارائه خدمات متنوع، يكى از يرمراجعلترين سازمانهاى دولتى است.

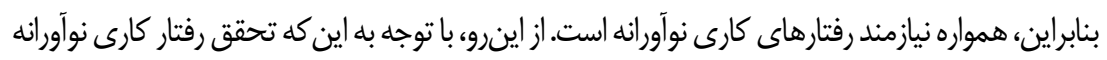

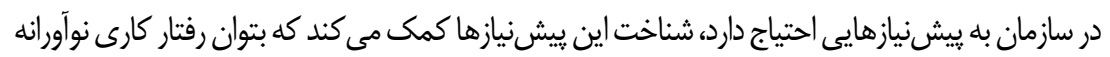

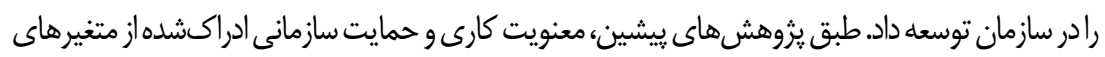

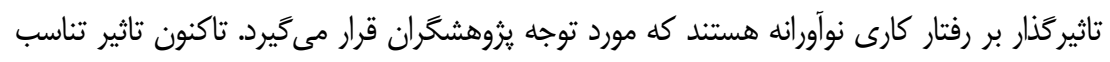

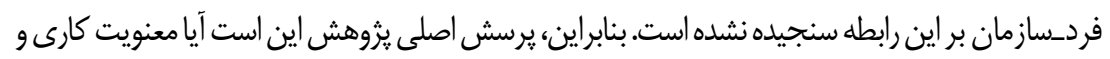

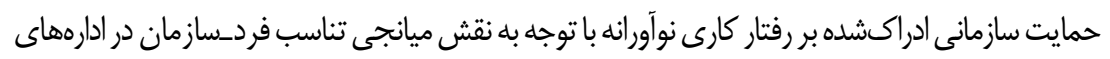

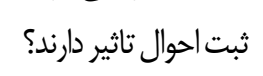

مبانى نظرى يزوهش

\section{معنويت كارى}

معنويت به مثابه نيرويى انرزىزا، انخَيزاننده، الهامبخش، و روحبخش در زندكى بهشمار مىرود.

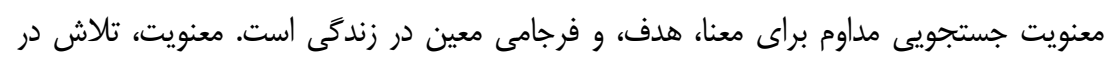

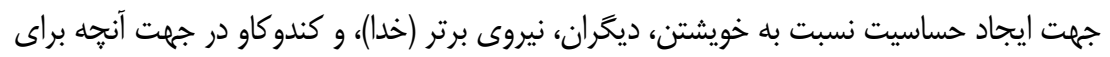
انسان شدن مورد نياز است و جستجو براى رسيدن به انسانيت كامل است (Pandey et al., 2019).

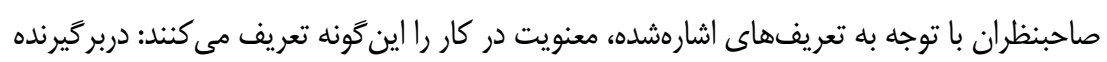

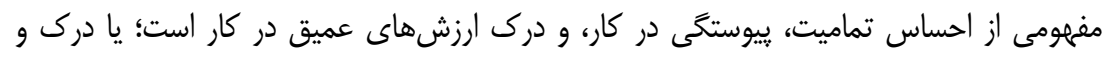

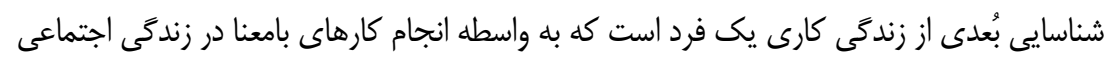

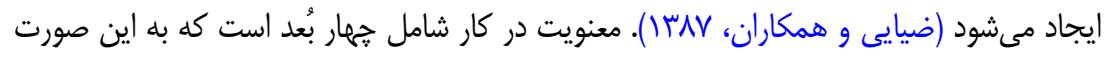

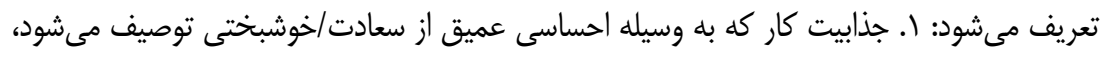

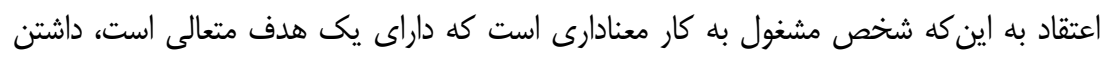

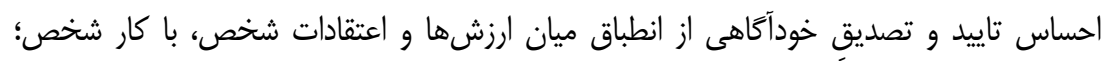

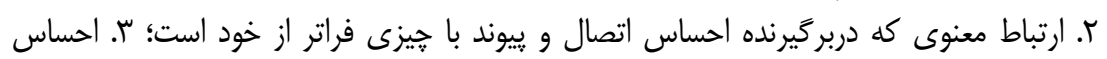

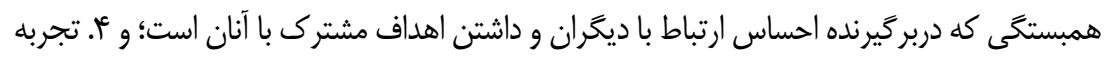

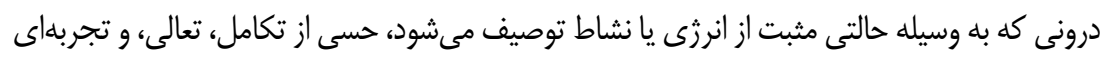
از شادى و سعادت (عابدى جعفرى و رستخار، عربا). 


\section{حمايت سازمانى ادراكشده}

حمايت سازمانى ادراكشده ريشه در نظريه مبادله اجتماعى دارد. نظريه مبادله اجتماعى يكى از نظريههاى مهمى است كه در بررسى كرايشهاى كارى كارمندان بكار مىرود. اين نظريه مبناى نظريههايى مانند حمايت سازمانى است كه به تبيين رفتار سازمانى مىيردازد (Deconinck, 2010).

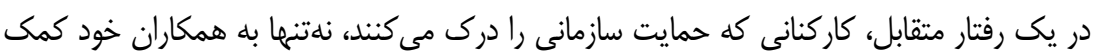

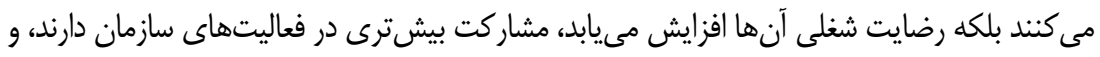

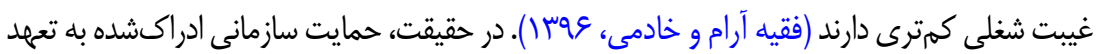

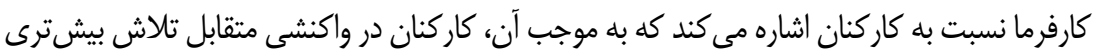

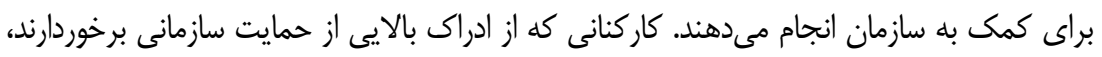

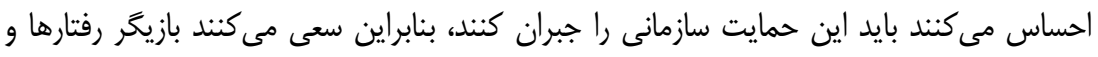
نغرش هاى مناسبى در سازمان باشند تا منافع سازمان را تامين نمايند (Eisenberger et al., 2001).

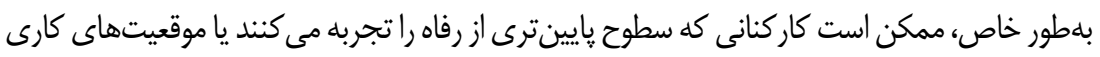

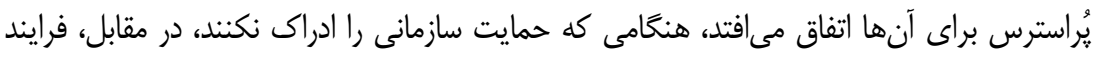

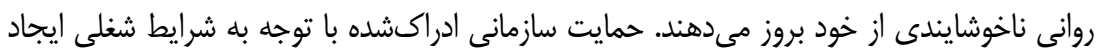

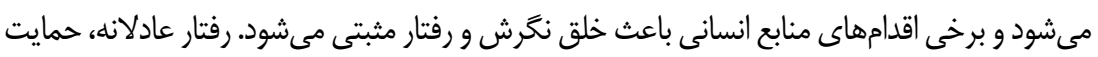

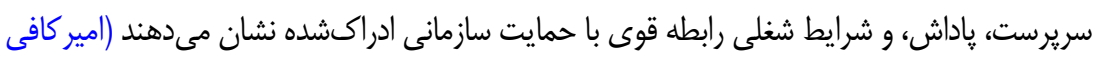

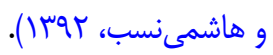

\section{رفتار كارى نوآورانه}

رفتار كارى نوآورانه، نوعى رفتارهاى شهروندى اختيارى است كه الزاماً در نقشها و شرح

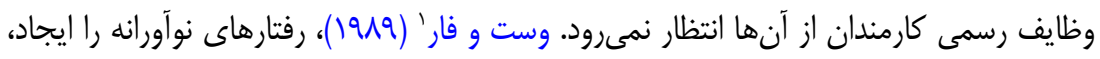

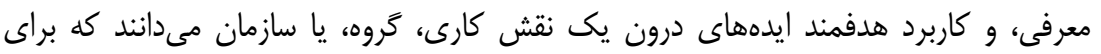

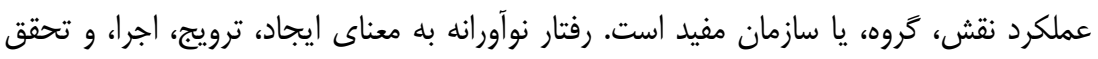

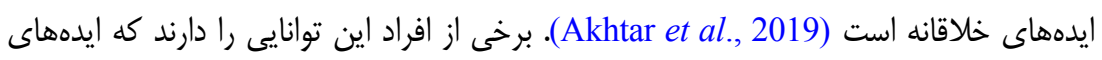

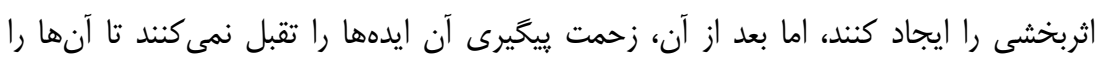

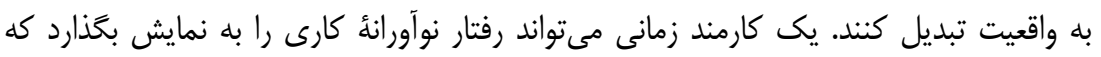


خلق ايده همراه با اجراى ايده باشد. بنابراين رفتار نوآورانه، عملى كردن افكار و انديشههاى نو إنات

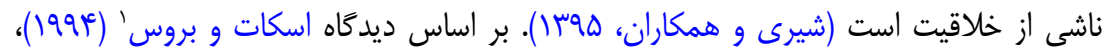

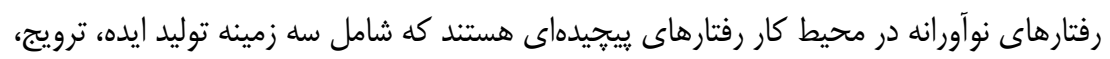

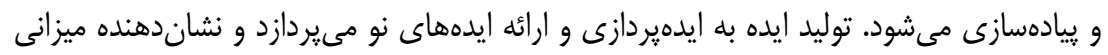

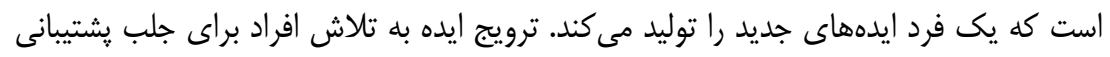

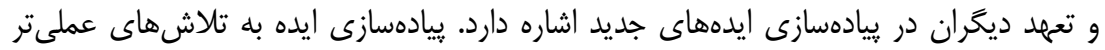

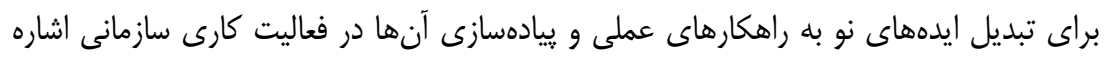
دارد (Scott \& Bruce, 1994)

\section{تناسب فردسـسازمان}

تناسب فردسازمان به تطابق بين ويثگى هاى فردى و سازمانى معطوف است و زمانى بلوجود

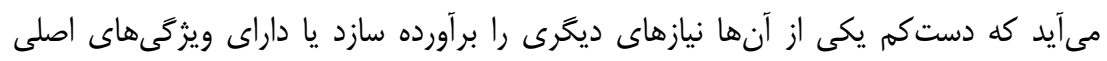

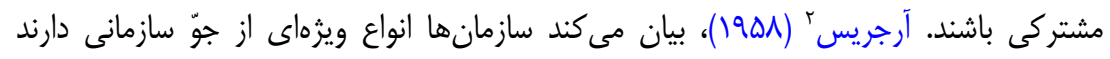

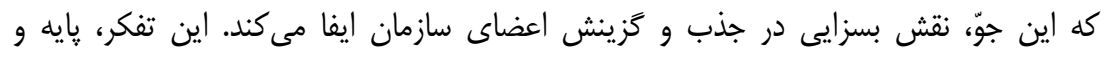

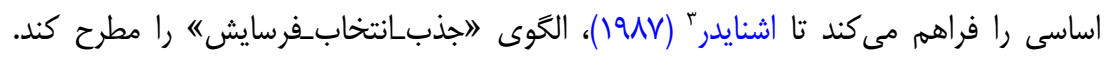

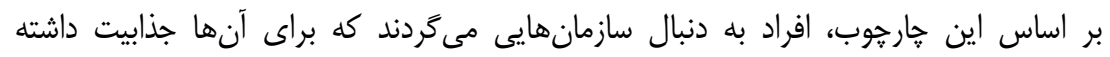

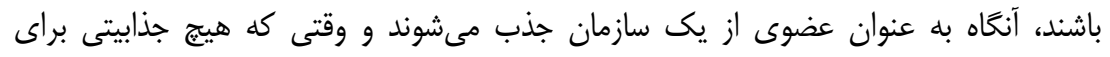
دو طرف (فرد و سازمان) وجود نداشته باشد، از سازمان خارج مى شئند (Schneider, 1987).

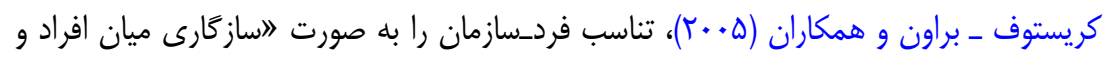

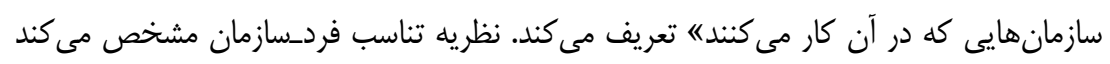

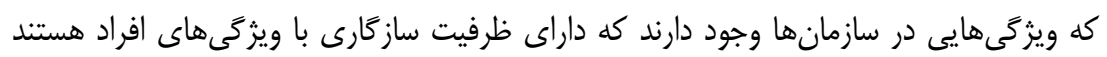

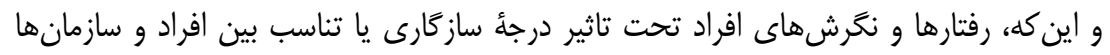

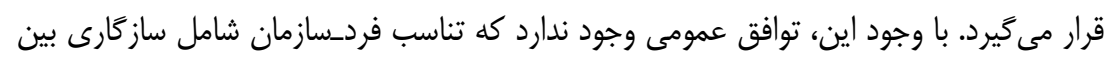
افراد و سازمانهايشان است، و ماهيت دقيق اين تناسب به تعريفهاى كيجكنندهاى از تناسب

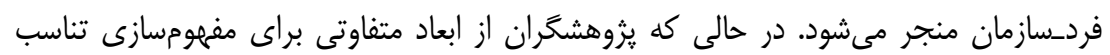

\section{Scott \& Bruce}

2. Argyris

3. Schneider 
فردسازمان استفاده مى كنند، بيشترين ابعاد مشترى براى سنجش اين تناسب شامل تناسب

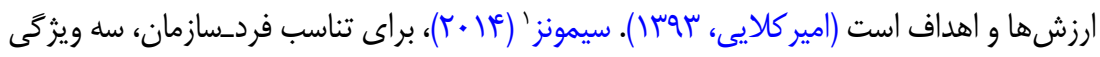

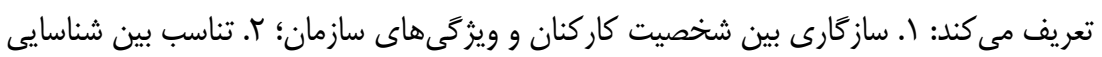
هدف كاركنان و سازمان؛ و س. تناسب و تجانس ارزشى سازمان و كاركنان. بنابراين، براى ايجاد

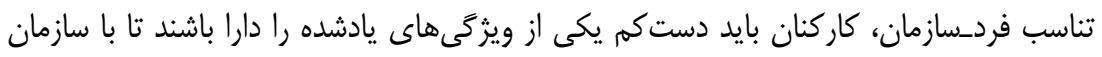

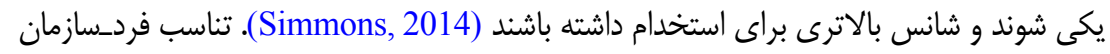

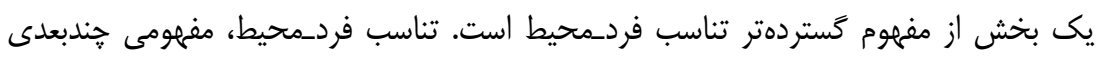

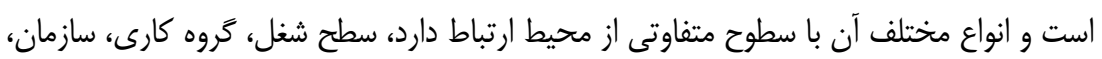

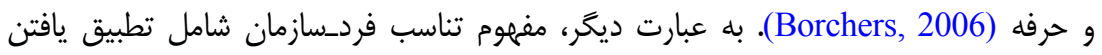

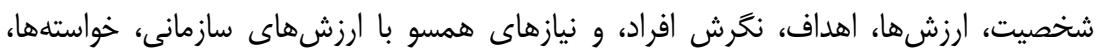

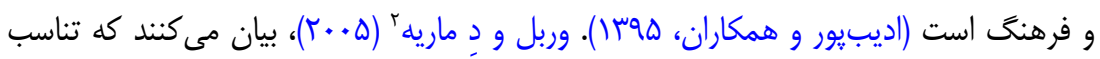

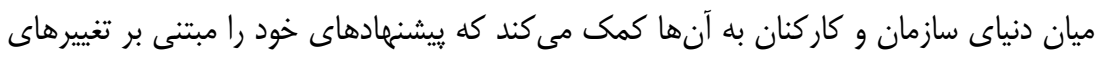

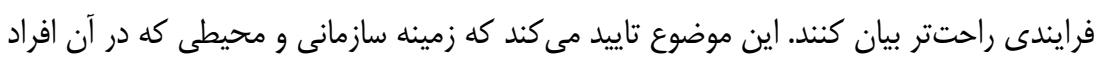

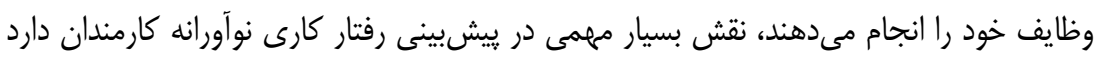

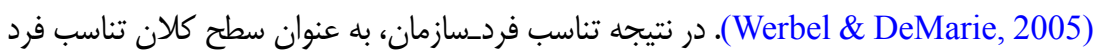

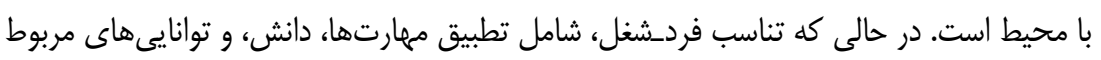

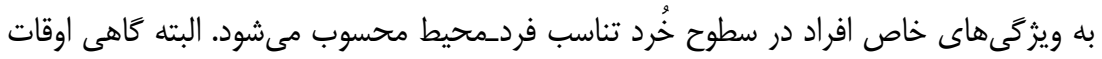

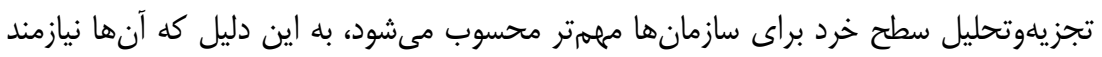

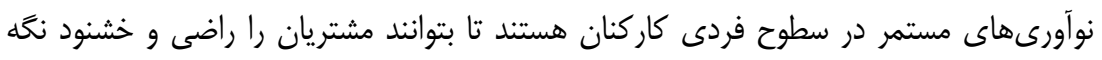
دارند؛ زيرا مشترى بيشتر به محصول اهميت مىدهد. با اين تفاسير، مىتوان دريافت كه كارئ كاركنان

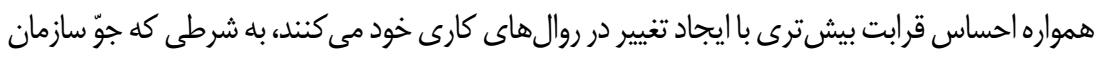

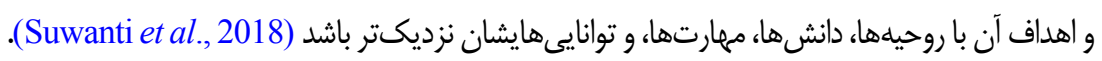

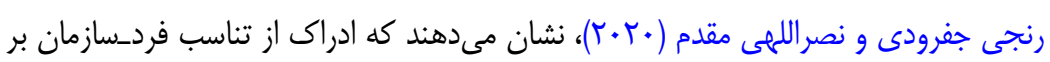

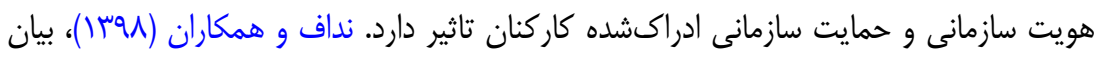

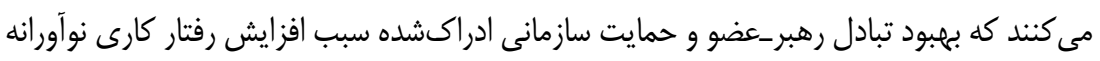

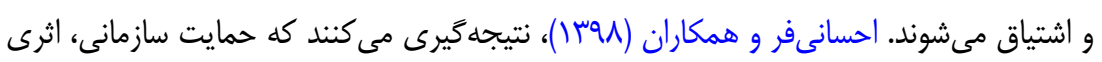

2. Werbel \& DeMarie 
معنادار بر عملكرد نوآورانه دارد. نتايج فقيه آرام و خادمى (عوسا)، نشان مىدهد كه حمايت و وار

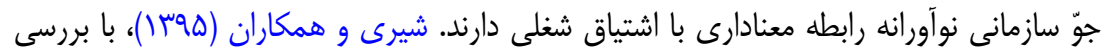

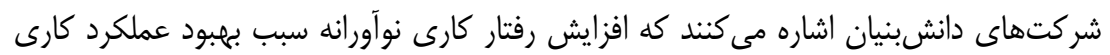

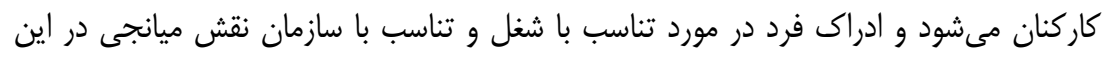

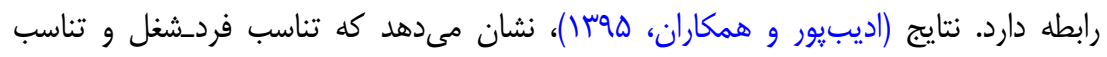
فردسسازمان بر رفتار كارى نوآورانه و رفتار كارى نوآورانه بر عملكرد شغلى كاركنان موثر است.

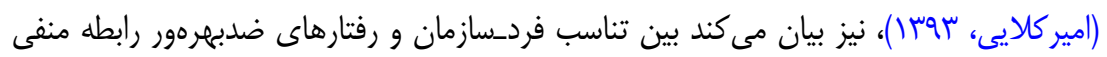

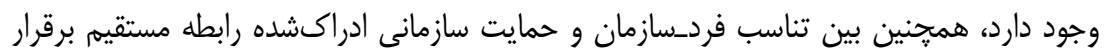

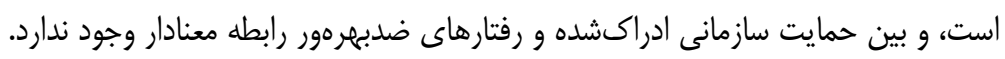

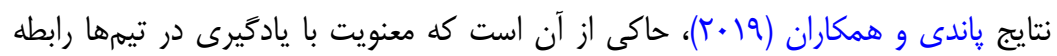
مثبتى دارد و يادَّيرى تيمى واسطه ارتباط بين معنويت و رفتارهاى نوآورانه در سطح تيم است.

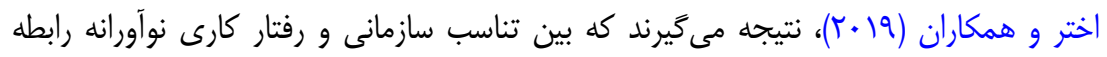
وجود دارد و حمايت سازمانى دركشده و تعهل عاطفى و اعتماد نقش ميانجى دارند. راناسينقه

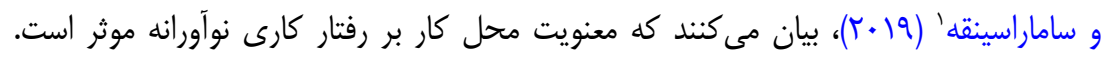

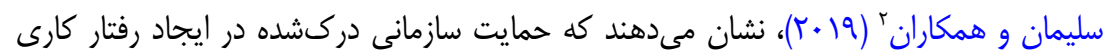

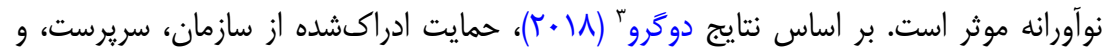

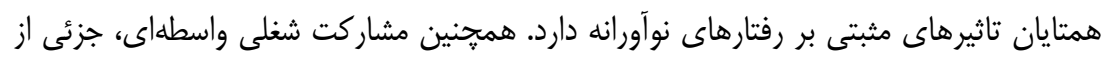

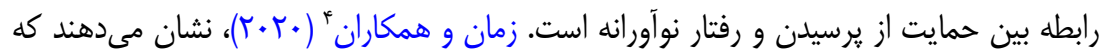

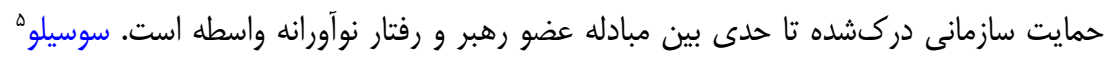

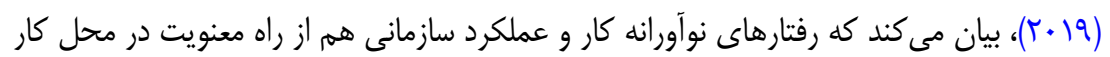

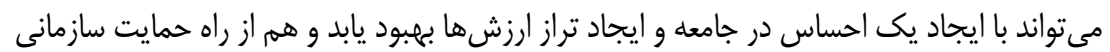

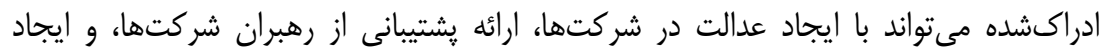

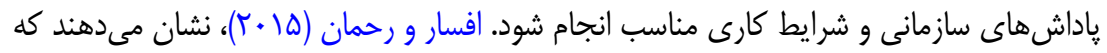
تناسب فردسازمان و مناسب بودن فرد و شغل با رفتار شهروندى سازمانى و رفتار كارى نوان نوآورانه

1. Ranasinghe \& Samarasinghe

2. Sulaiman et al.

3. Doğru

4. Zaman et al.

5. Susilo 
رابطه مثبت دارد، و برخلاف انتظار، رفتار شهروندى سازمانى با رفتارهاى كارى نوآورانه ارتباطى

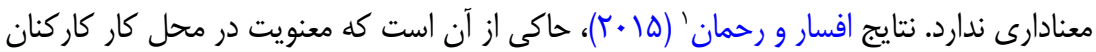

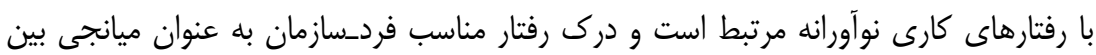
معنويت محل كار و رفتار كارى نوآورانه ارتباط دارد.

\section{توسعه فرضيه هاى ثئوهش}

بررسى منابع موجود در معنويت نشان مىدهد كه در درك تناسب فرد با سازمان، كارمندان

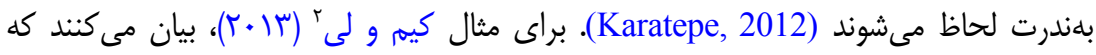

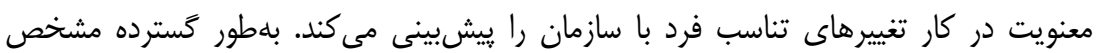

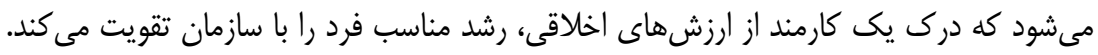

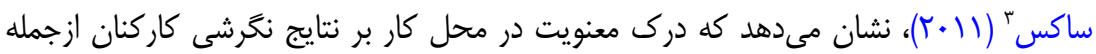

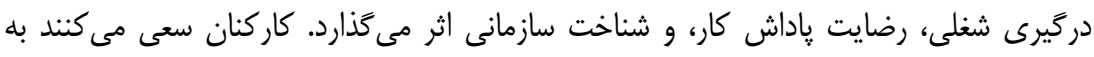

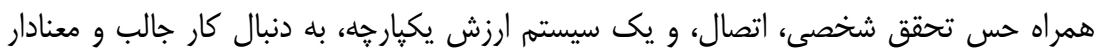
باشند (Rego \& e Cunha, 2008). بنابراين فرض مى شود: _ معنويت كارى بر تناسب فردسازمان اثر مثبت و معنادارى دارد.

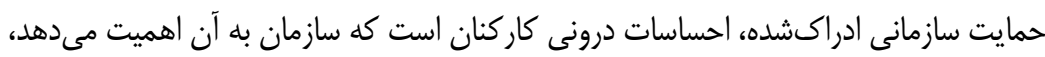

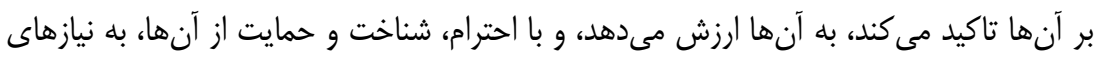

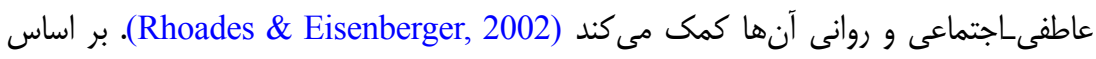
اصل متقابل، فرد داراى حمايت سازمانى ادراكشده منابع عاطفىاجتماعى راعى را از سازمان دريافت

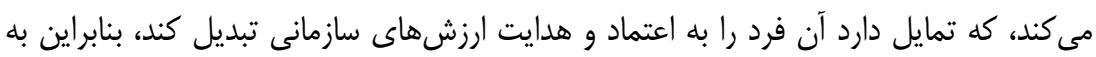

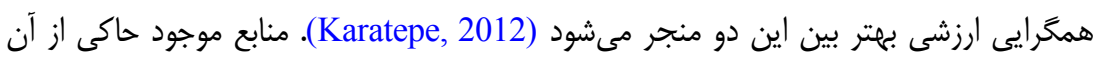

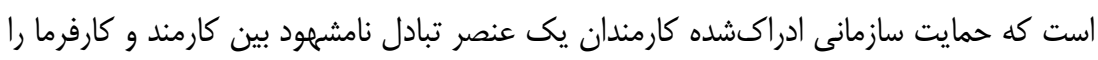

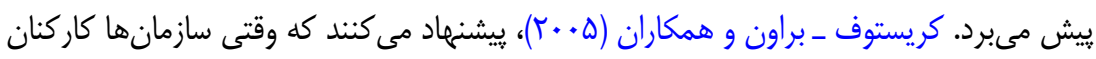

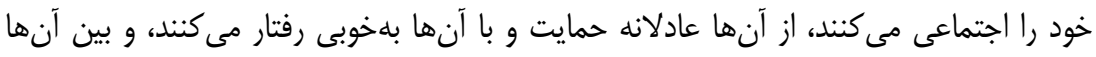

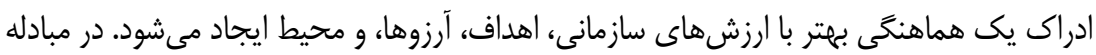

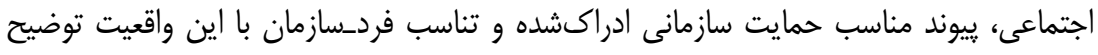

1. Afsar \& Rehman

2. Kim \& Lee

3. Saks 
داده مىشود كه كارمندى كه نيازهاى عاطفىاجتماعى و ارزشمندى در آن بها داده مى آشود، احساس مى كند كه از راه افزايش عملكرد فوقالعاده نقش خود، با ايدئولوزى تبادل قوى و تناسب إناس فردسازمان مىتواند به سازمان خدمت كند (Kristof-Brown et al., 2005). بنابراين، حمايت سازمانى ادراكشده ممكن است به تناسب فردساز مان مربوط شود، زيرا درك عمومى يلى يكى كارمند

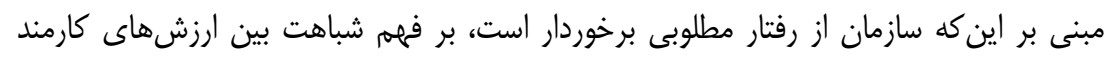

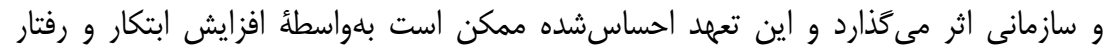

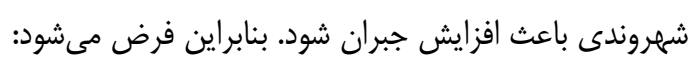

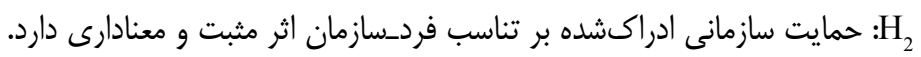

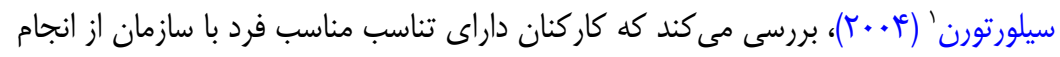

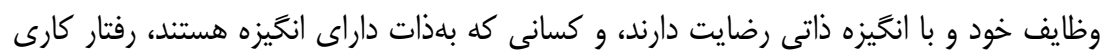

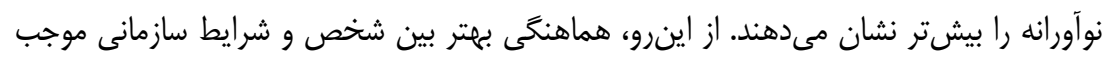

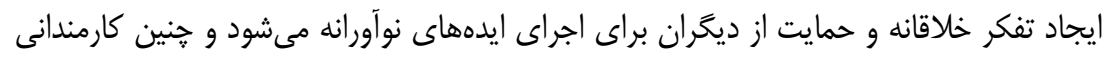

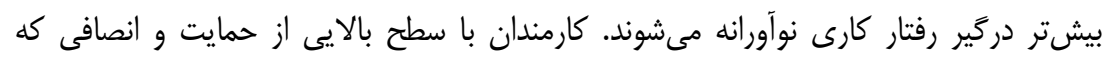

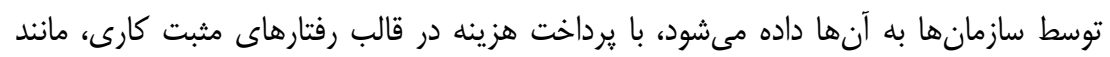

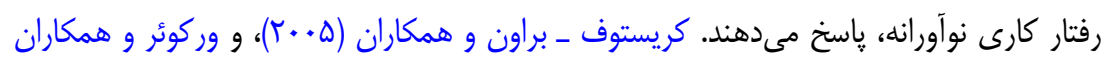

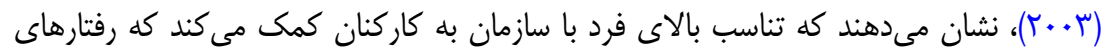

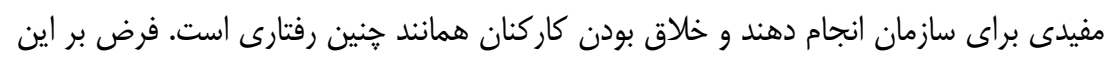

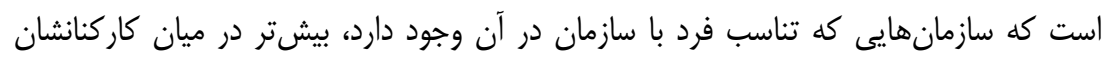

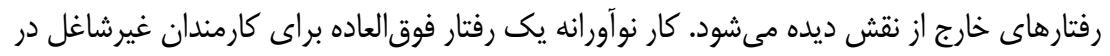

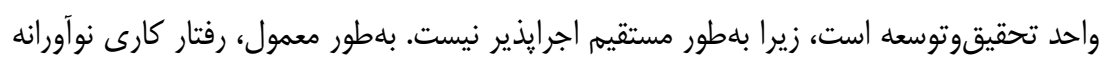

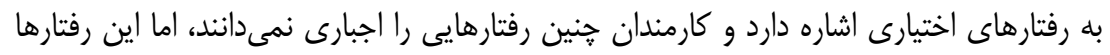

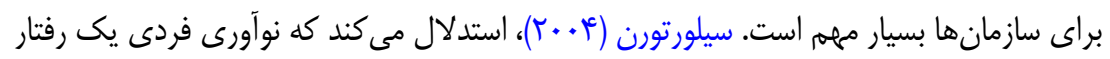

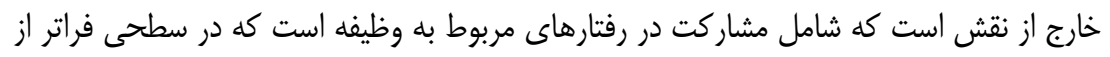

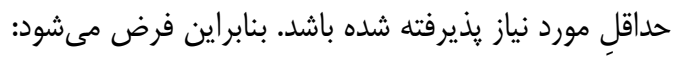

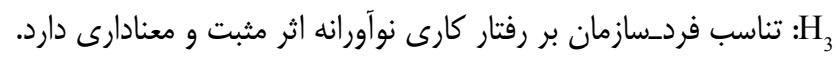

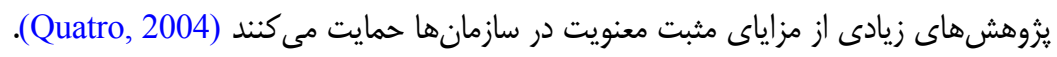

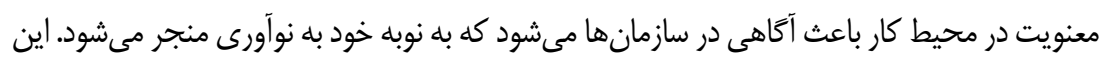


امر مىتواند افراد را به سمت آكاهى در سطح عميقتر سوق دهد. آنان از اين راه توانايىهاى شهودى

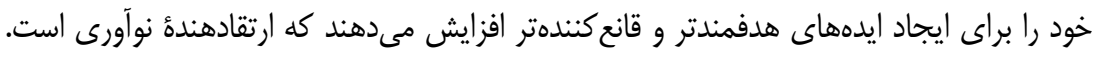
معنويت، احساس تعهد و وفادارى را نسبت به سازمان تقويت مى كند (Rego \& e Cunha, 2008).

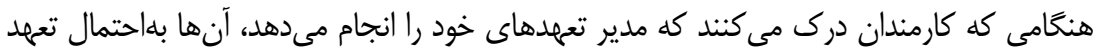

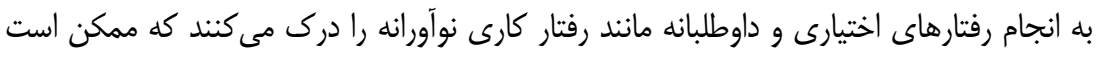

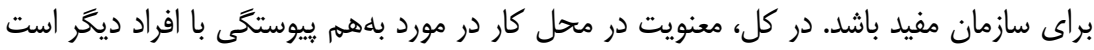

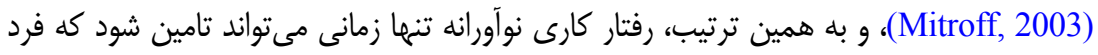

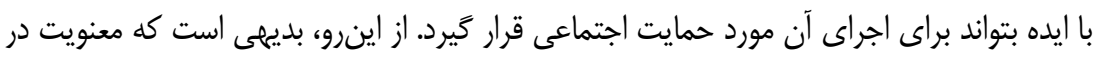

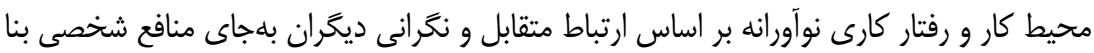

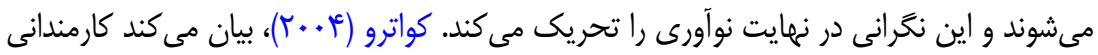

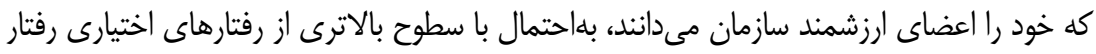

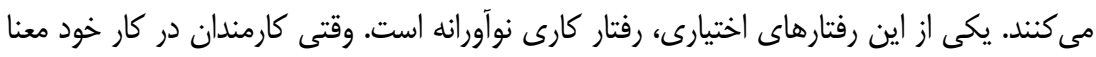

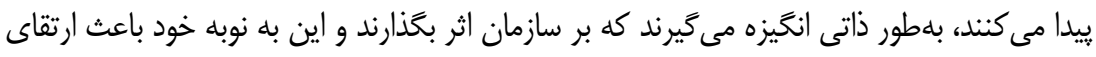

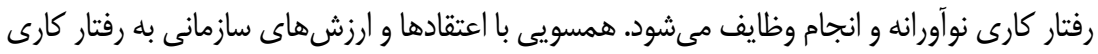

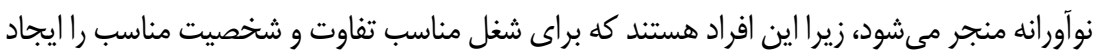

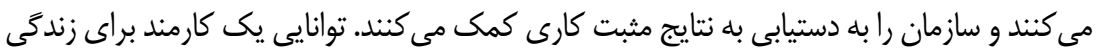

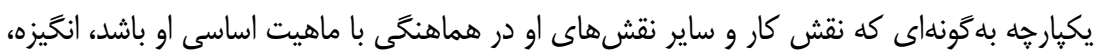

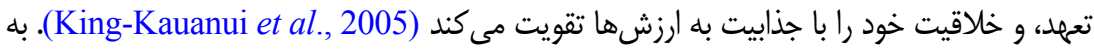

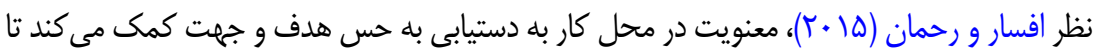

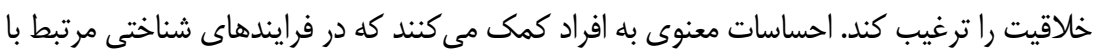

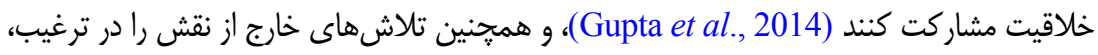

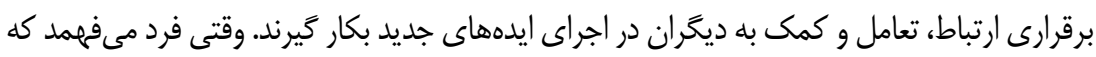

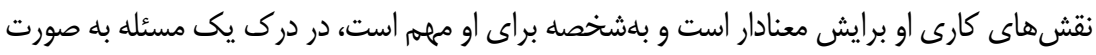
مستحكمترى دركير مىشود و راهحل هاى جديد را جستجو مى كند (Gilson \& Shalley, 2004).

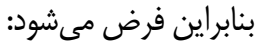

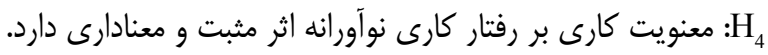

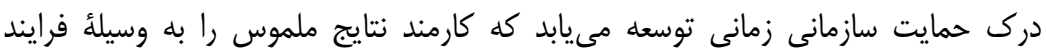

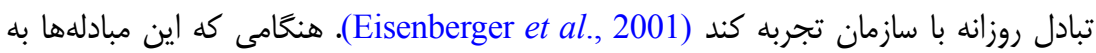


نتايج مثبتى منجر شوند، فعاليتهاى خارج از نقش كاركنان آغاز مىشود. ترَّورى و همكاران'

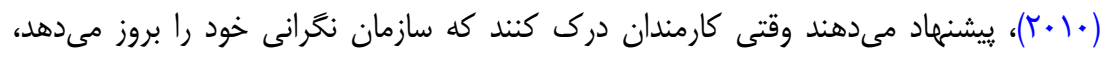
بازخورد غيرقضاوتى و صادقانهاى راجع به كار خود ارائه مىدهند و با تمايل به شروع ايدههاى

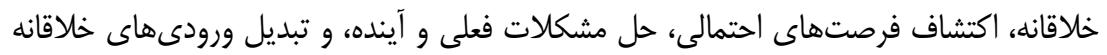

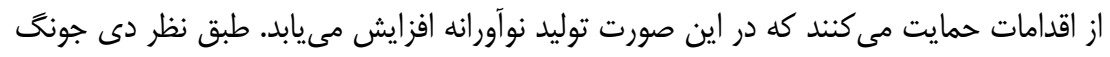

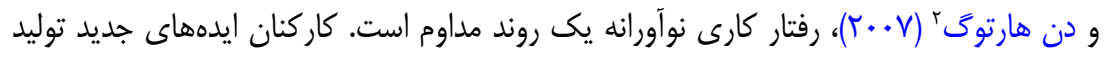

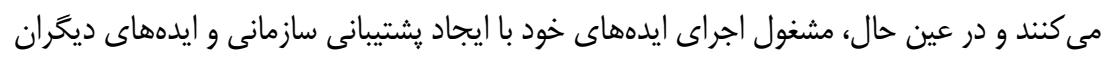

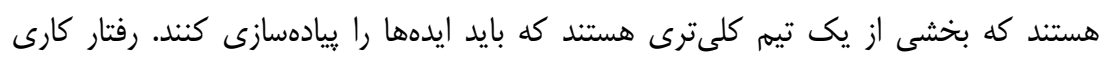

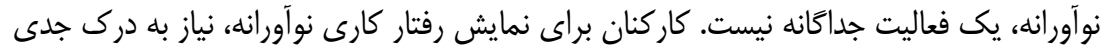

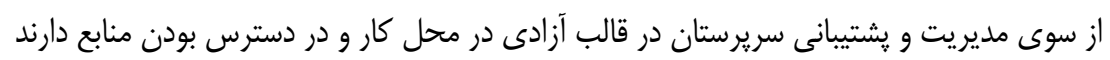

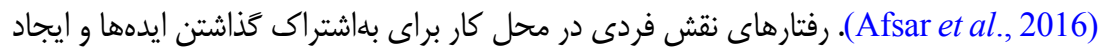

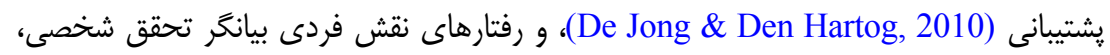
انعطافيذيرى، ريسكيذيرى، و بىباكى است (Lee et al., 2014). بنابراين، انتظار مىرود كه

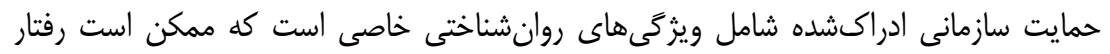

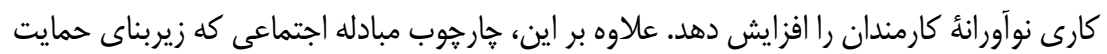

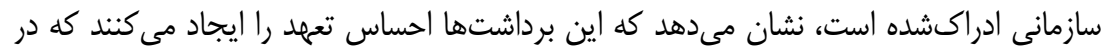

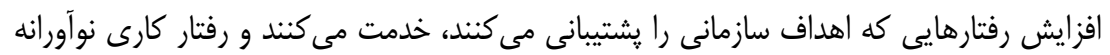
يكى از اين رفتارهاى مثبت است. به دليل احساس تعهد، حمايت سازمانى ادراكشده به رفتار رهاى

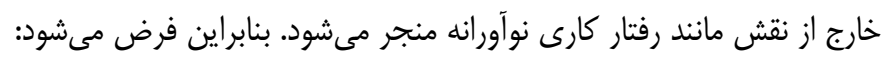

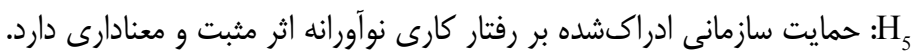

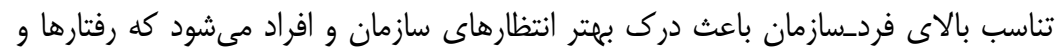
نكرشها را مىتوان متناسب با انتظارها تحريك كرد و باعث ايجاد يك احساس منحصر به فرد شد (Gregory et al., 2010). ارضاى نيازهاى معنوى در محيط كار به كاركنان كمك مى كند كه احساس منحصر به فرد بودن خود را دنبال كنند و بيشتر در يك زمينه شايسته كر دند. انسجام

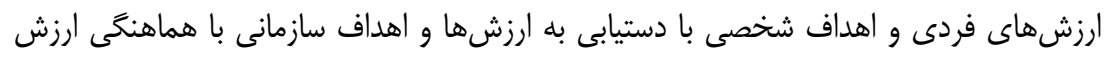

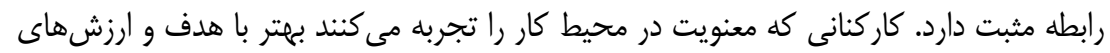


سازمان مطابقت دارند و زندگى يكيار קهاى را در سازمانها جارى مىسازند. اين امر كمك مى كند

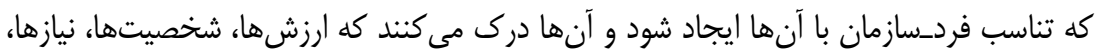

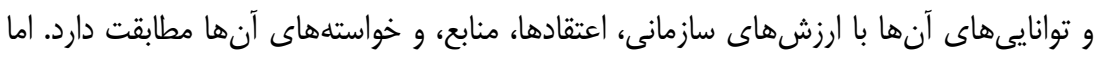
اكر كاركنان سطح معنويت كمترى در محيط كار تجربه كنند، درك آنها از تناسب فردمسازمان

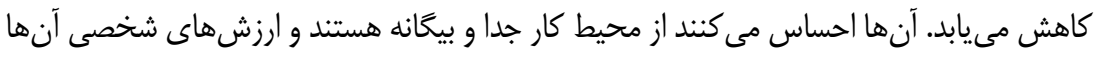

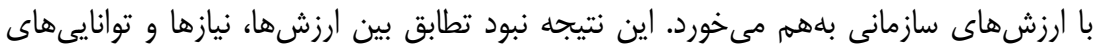

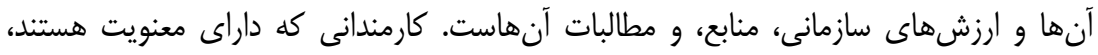

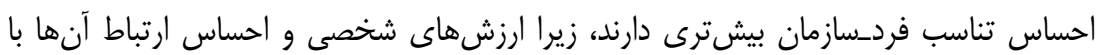

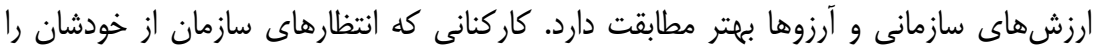

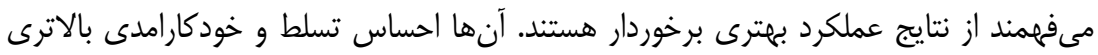
نسبت به وظايف و محيط كار دارند و بر نتايج راهبردى، عملكردى، ادارى، و عملياتى در محل

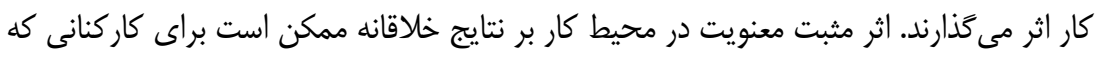

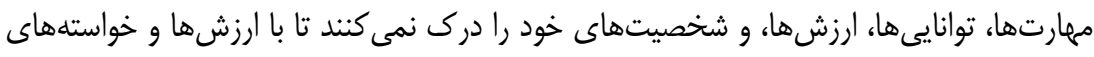

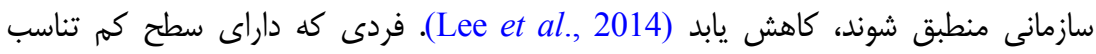

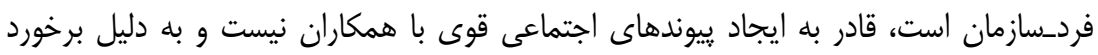

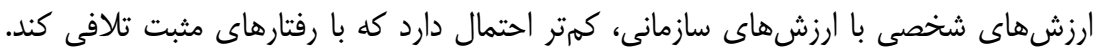

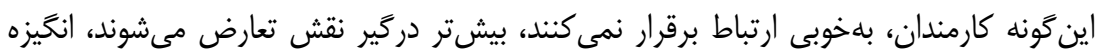

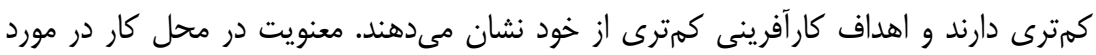

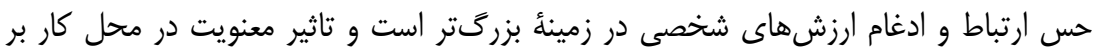

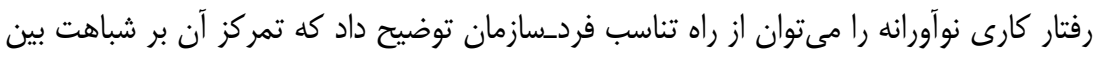

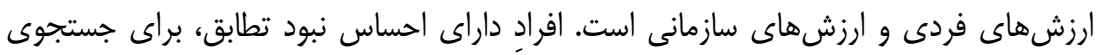

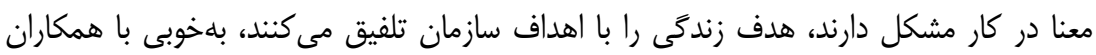

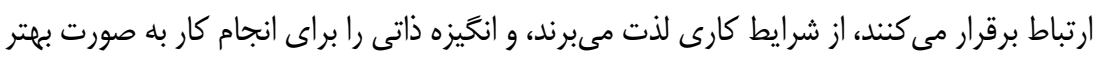

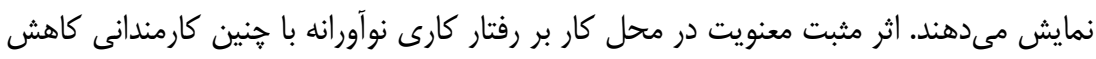

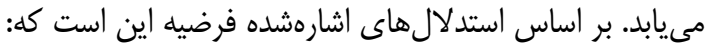

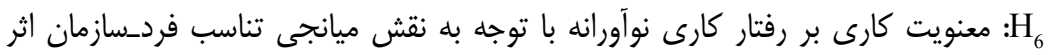

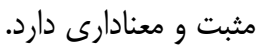
رفتار منصفانه و پشتيبانى سازمانى ممكن است روند تفكر خلاق را بين كارمندان افزايش 
دهد و يبادهازى ايدههاى جديد را تسهيل كند. اما اين رابطه تا حدودى با مطابقت بين ارزشها،

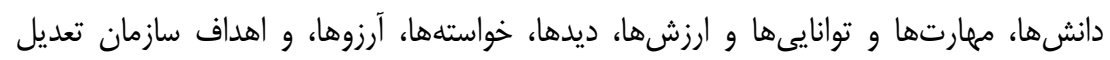

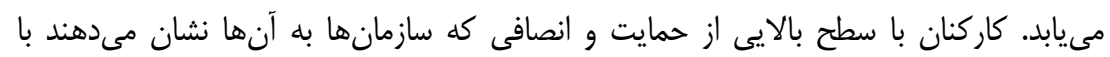
جبران نمودن در قالب رفتارهاى مثبت كارى مانند رفتار كارى نوآورانه پاسخح مىدهند. تناسب

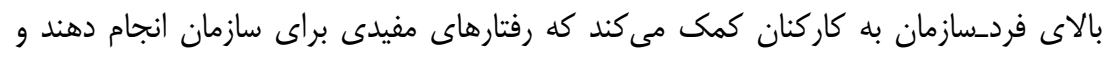

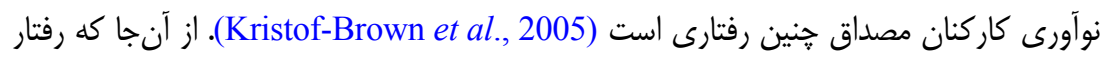

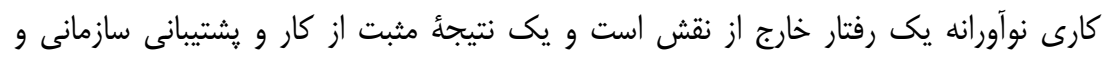

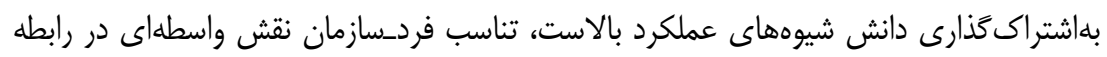

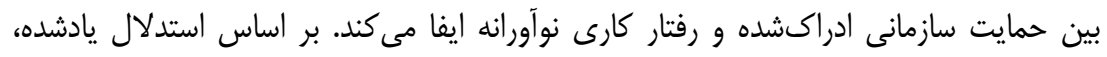

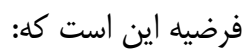
فر فردسازمان اثر مثبت و معنادارى دارد.

\section{الكوى مفهومى بزووهش}

هدف اين بزوهش، بررسى تاثير معنويت كارى و حمايت سازمانى ادراكشده بر رفتار كارى

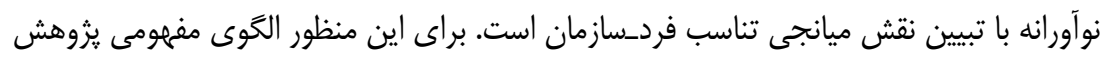
مطابق شكل (ا) ارائه مىشود. متغيرهاى مستقل يزوهش، معنويت كارى و حمايت سازمانى فئى

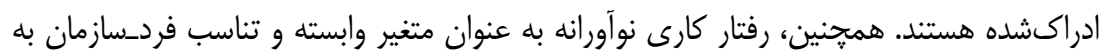

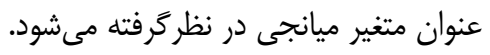

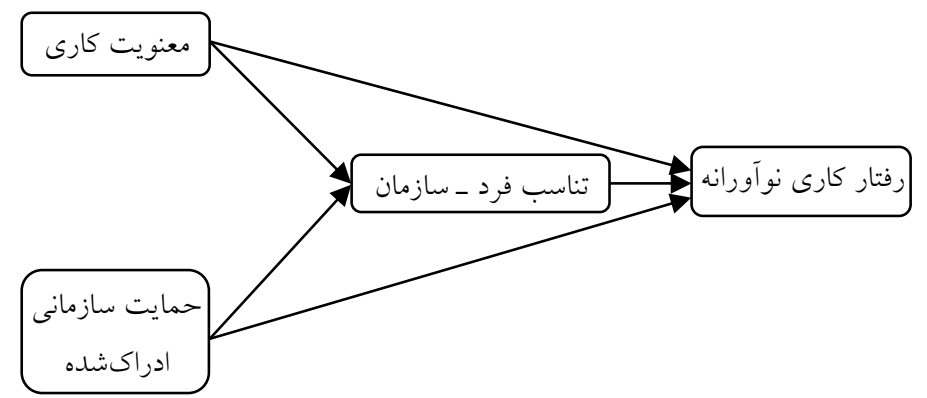

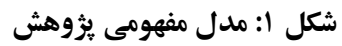




\section{روششناسى بؤوهش}

اين يزوهش در راستاى هدفى كه دارد، كاربردى است، زيرا از نتايج آن مىتوان در تصميمَّيرى

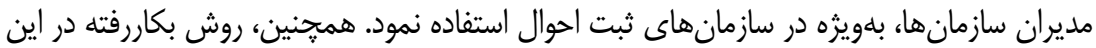
يزوهش برحسب ماهيت از نوع توصيفى_ييمايشى است. در اين روش، يزوهشكران شرايط فعلى را

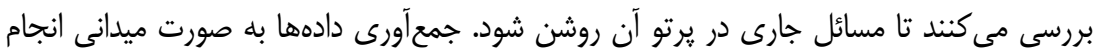

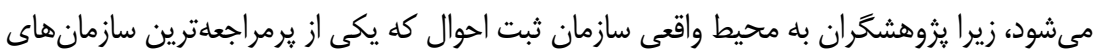

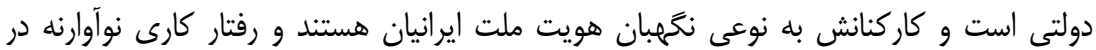

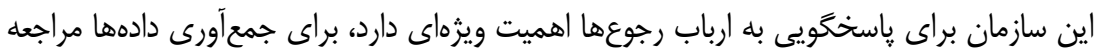
مى كنند. جامعه آمارى يزوهش، شامل كليه كاركنان سازمان ثبت احوال استان كلستان است كه تعداد

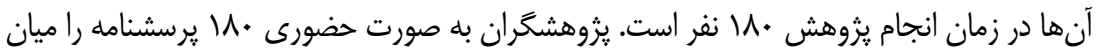

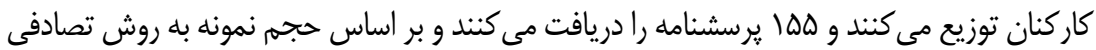

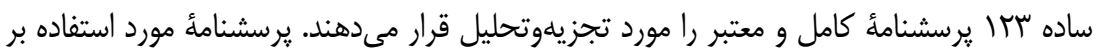

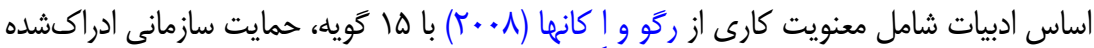

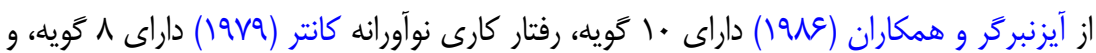
تناسب فردسازمان افسار و رحمان (ه| +r) داراى ها كويه است. مقياس مورد استفاده در يرسشنامهها

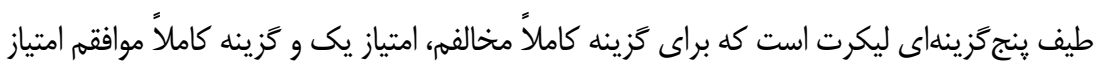

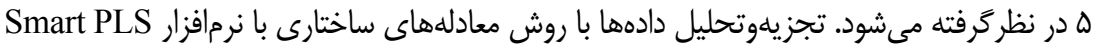

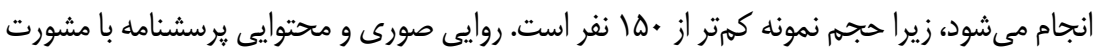

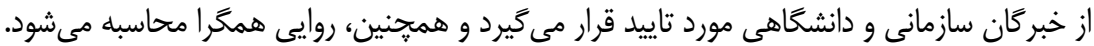

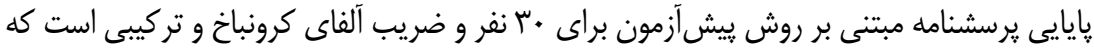

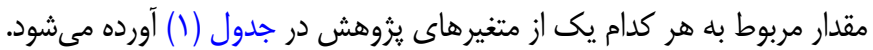

جدول ا: يايايى و روايیى براى هر يك از متغيرهاى برسشنامه

\begin{tabular}{|c|c|c|c|}
\hline ميانخين واريانس استخراجى & بايايى تركيبى & آلفاى كرونباخ & متغير \\
\hline$\cdot / \Delta V V^{c}$ & $\cdot / A V \wedge$ & - / 149 & معنويت كارى \\
\hline$\cdot / \Lambda \mu K$ & $\cdot /$ VA & - RIT & حمايت سازمانى ادراكشده \\
\hline$\cdot / 094$ & $\cdot / 119$ & - /var & رفتار كارى نوآورانه \\
\hline . $/$ ors & - /ATH & - Nar & تناسب فرد_سازمان \\
\hline
\end{tabular}


با توجه به اينكه مقدار مناسب آلفاى كرونباخ و پايايى تركيبى V/• و AVE D/• است،

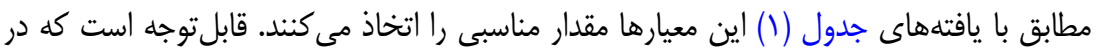

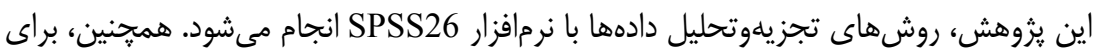
تحليل مسير از مدلسازى معادلهاى ساختارى و نرمافزار Smart-PLS2 استفاده مى شودد.

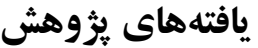

ييش از ارائه نتايج مربوط به آزمون فرضيههاى يزوهش، نتايج توصيفى مربوط به ويثگى هاى

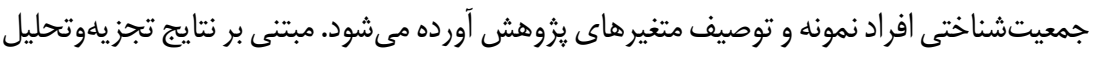
انجامشده در خصوص ويزَى هاى جمعيتشناختى از نظر جنسيتى، (9.1 نفر) عم درصد مرد و

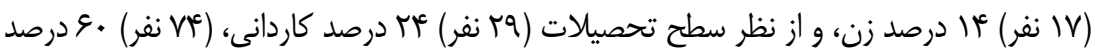

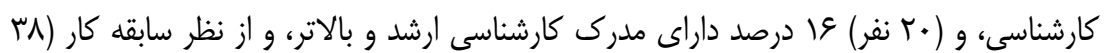

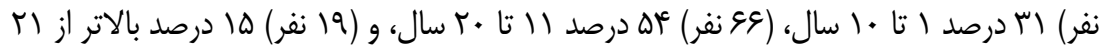

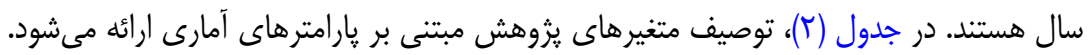

جدول r: شاخصهاى توصيفى متغيرهاى ثئوهش

\begin{tabular}{lcccccccc}
\hline متغيرnn & \\
\hline
\end{tabular}

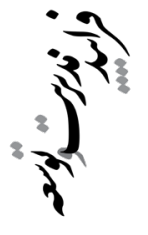

مبتنى بر جدول (ז)، براى تمام متغيرها، ميانگين محاسبهشده بيشتر از ميانخين نظرى (عدد س) است. همجنين، بيشترين مقدار ميانگين به متغير حمايت سازمانى ادراكشده و كمترين ميانگين به متغير رفتار كارى نوآورانه مربوط است. حال با استفاده از روش مدلسازى معادله مهاى ساختارى به ميه تحليل فرضيههاى يزوهش يرداخته مىشود. مدل معادلههاى ساختارى خانوادهاى از تكنيكهاى آمارى است كه براى تجزيهوتحليل سيستماتيك دادههاى جندمتغيره براى اندازهگيرى ساختارهاى

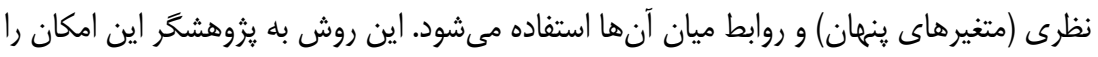


مى دهد كه يك فرضيه را به يك مدل آزمايشى تبديل كند (برمر و همكاران، لوجسا). بر اساس روش معادلههاى ساختارى، ضرايب استاندارد مسير و ضرايب معنادارى متغيرهاى الدائ يزوهش بلهدست مى آيد كه به صورت خلاصه در جدول (َآ) آورده مى شود.

\section{جدول "ا: بررسى معنادارى ضرايب مسير و آزمون روابط مستقيم متغيرها}

\begin{tabular}{|c|c|c|c|}
\hline $\begin{array}{c}\text { خر يب معنادارى } \\
\text { (t) }\end{array}$ & ضريب مسير & 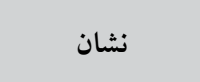 & روابط متغيرها \\
\hline $9 / 90$ & $\cdot / 099$ & FPO --- WS & معنويت كارى ـ \\
\hline N/VET & $\cdot$ /VAV & FPO --- ROS & حمايت سازمانى ادراكشده ـ ـ تناسب فردسسازمان \\
\hline $9 / T Q 9$ & $\cdot / A \cdot r$ & IWB --- FPO & تناسب فردسسازمان ـ ـ رفتار كارى نو آورانه \\
\hline$\Delta / \cdot \wedge r$ & $\cdot / 411$ & IWB --- WS & معنويت كارى ـ > رفتار كارى نوآورانه \\
\hline $9 / 1 \cdots$ & $\cdot /$ orr & IWB --- ROS & حمايت سازمانى ادراكشده ـ ـ رفتار كارى نو آورانه \\
\hline
\end{tabular}

بر اساس جدول (ب)، ضر ايب استانداردشده مسير و معنادارى نشان مىدهد كه معنويت كارى

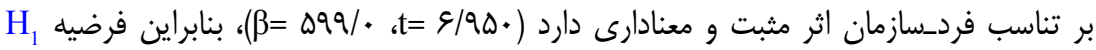
تاييد مى گردد. حمايت سازمانى ادراكشده بر تناسب فرد_سازمان اثر مثبت و معنادارى دارد

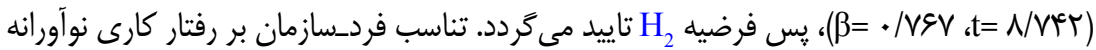

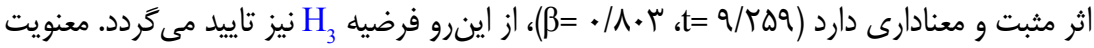

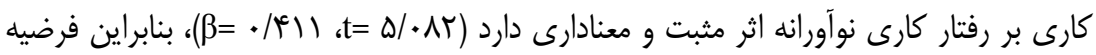

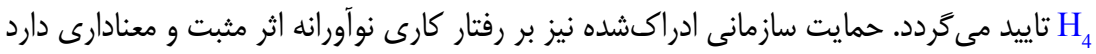

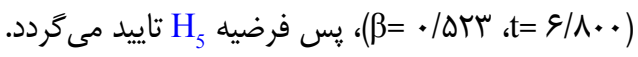

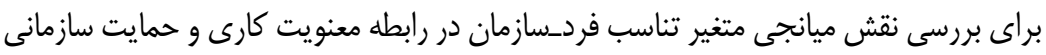

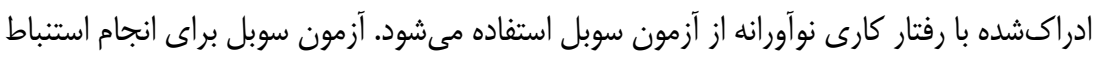

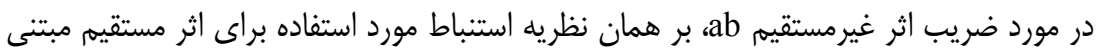

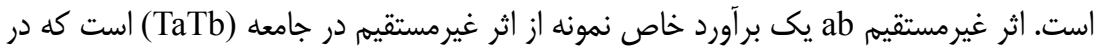

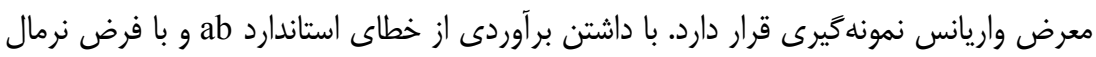

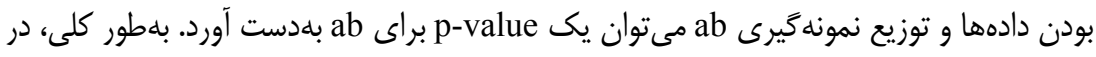

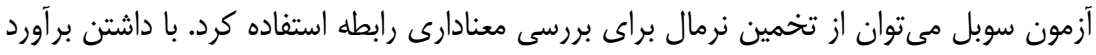

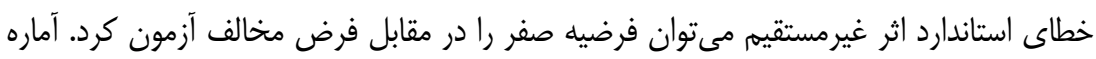


Z برابر است با نسبت ab به خطاى استاندارد آن. جدول (أ)، نتايج آزمون سوبل را نمايش مىدهد.

جدول ثا: بررسى معنادارى ضرايب مسير و آزمون روابط غيرمستقيم متغيرها

\begin{tabular}{|c|c|c|}
\hline 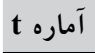 & ضريب مسير غيرمستقيم & مسير رابطه ميانجى \\
\hline $9 / 9$. & $\cdot / 099 x \cdot / \Lambda \cdot r=\cdot / 4 \wedge$. & معنويت كارى ـ ـناسب فردسسازمان ـ ـ رفتار كارى نو آورانه \\
\hline $11 / .9$ & $\cdot / V 9 V X \cdot / \Lambda \cdot r=\cdot / 910$ & 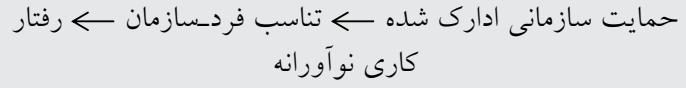 \\
\hline
\end{tabular}

بر اساس جدول (())، ضريب مسير غيرمستقيم اثر معنويت كارى بر رفتار كارى نوآورانه از راه متغير تناسب فردسازمان •^^^/ • و ضريب غيرمستقيم اثر حمايت سازمانى ادراكشده بر رفتار

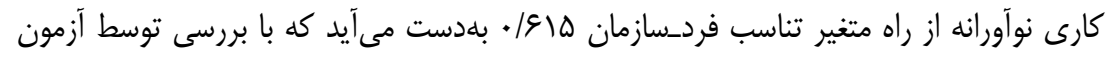

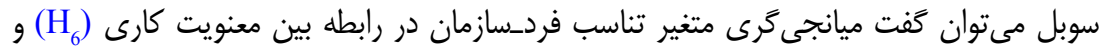

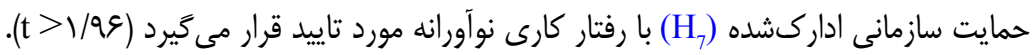

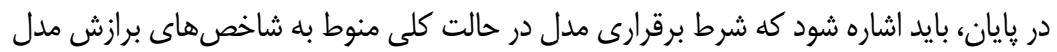

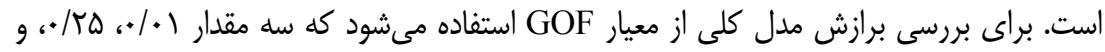

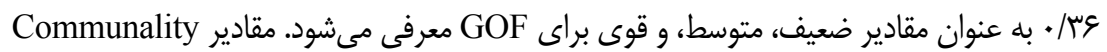

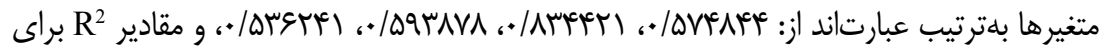

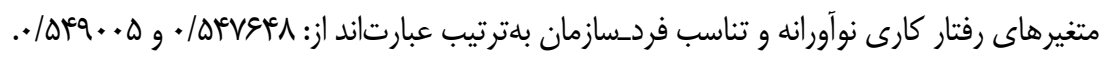

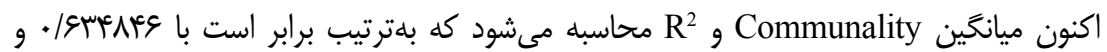

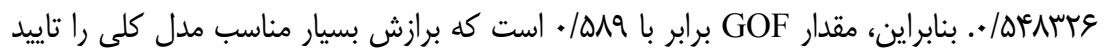

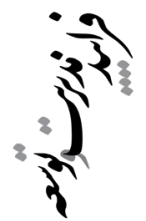

\section{بحث و نتيجه كيرى}

يزوهش حاضر با هدف تعيين تاثير معنويت كارى و حمايت سازمانى ادراكشده بر رفتار كارى

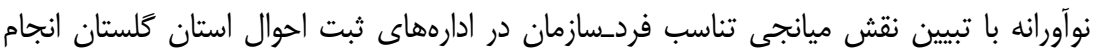

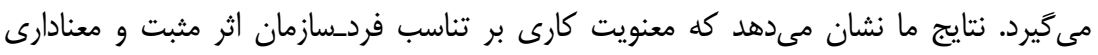

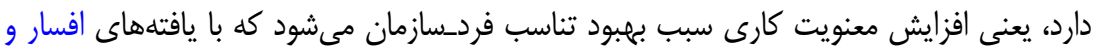

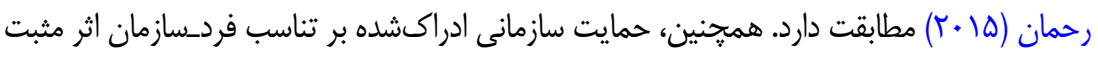


و معنادارى دارد، به اين معنا كه افزايش حمايت سازمانى ادراكشده سبب بهبود تناسب فردسازمان

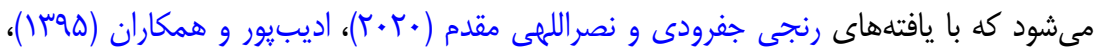

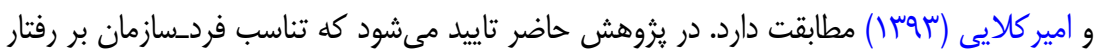

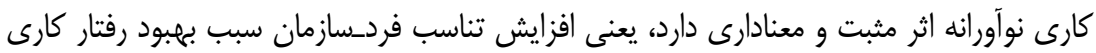

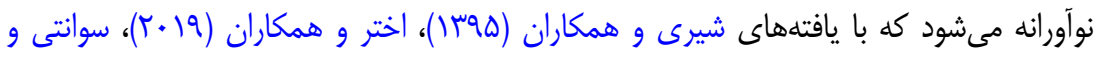

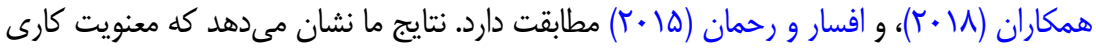

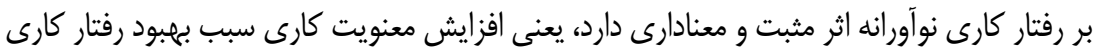

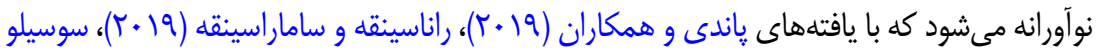

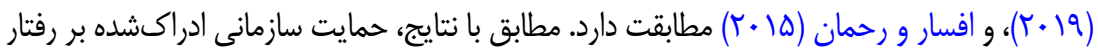

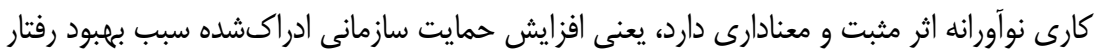

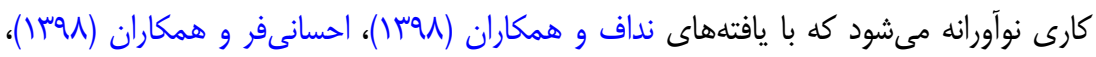

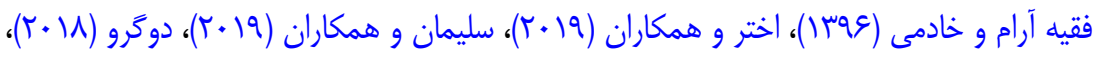

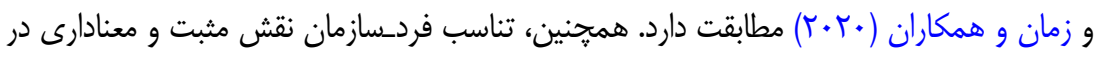

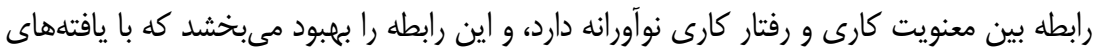

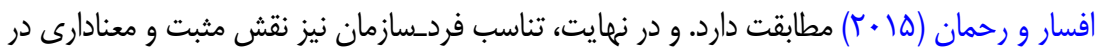

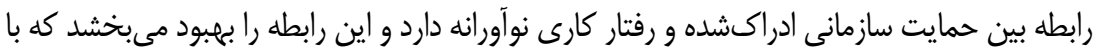
يافتهاى اختر و همكاران (19 + (T) مطابقت دارد.

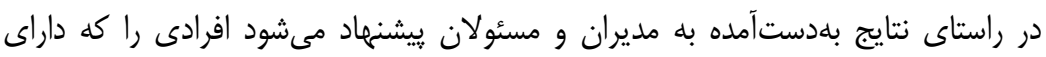

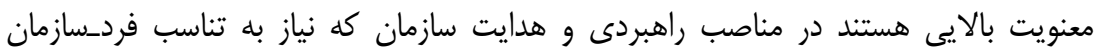
بالايى دارد، بكار كيرند و به منظور نهادينه كردن معنويات در سازمان، منشور معنوى تدوين

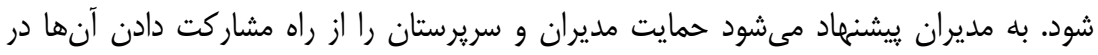
تصميمَّيرىها، ارائه بازخورد شغلى مناسب، و رفتارهاى محترمانه حفظ كنند، هرا كهان كاركنان

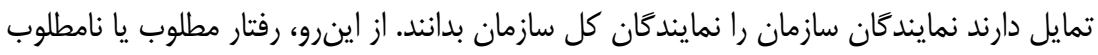

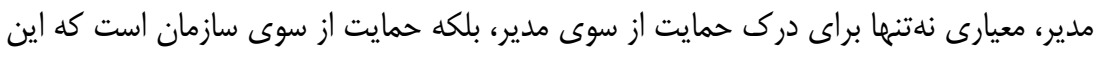

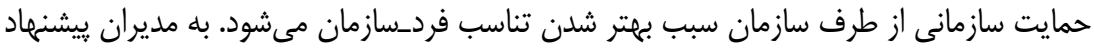

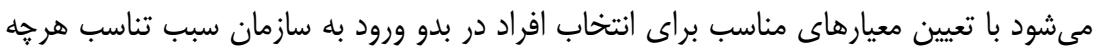

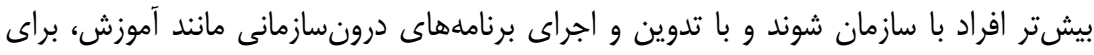

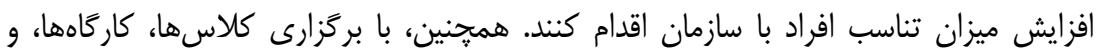


جلسههاى ويزه براى يرورش و رشد معنويت كاركنان از راه آموزش مهارت تفكر انتقادى وجودى،

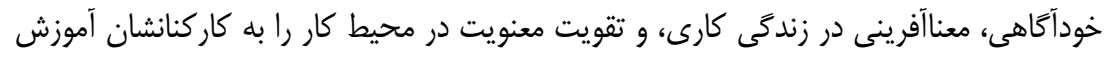

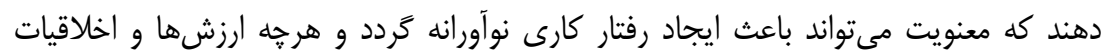

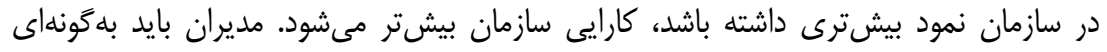

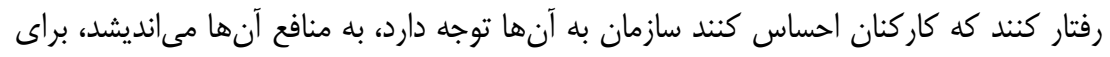

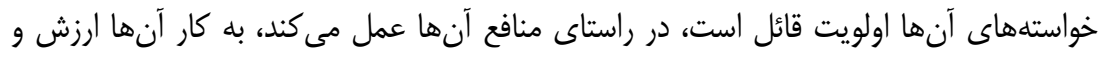

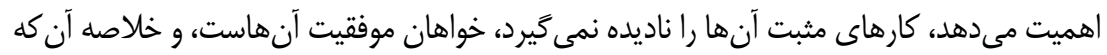

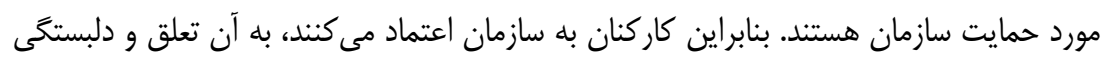

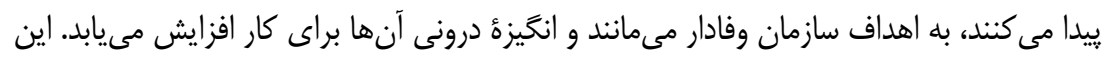

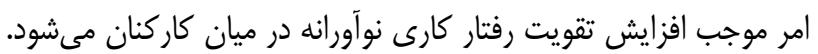

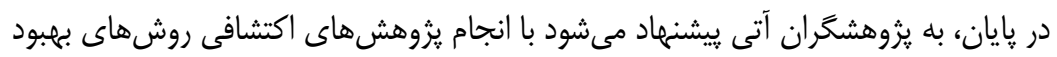

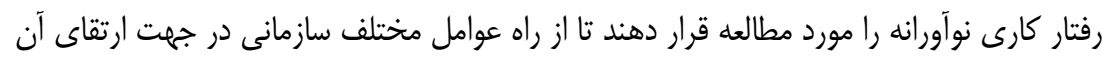

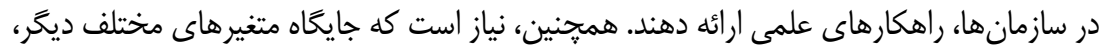
ازجمله مديريت مشاركتى و مديريت عملكرد به عنوان متغيرهاى اثركذار بر رفتار كارى نوآورانه

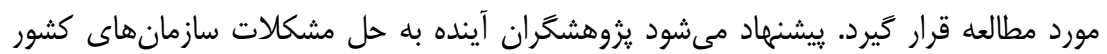
ازجمله تناسب فردسازمان در جهت رفتار كارى نوآورانه كاركنان كمك كنند.

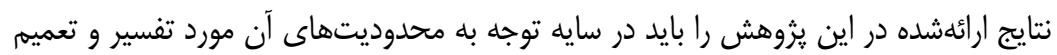
قرار داد. يكى از محدوديتهاى اصلى يزوهش حاضر اثر روش واريانس مشترك است، زيرا همه

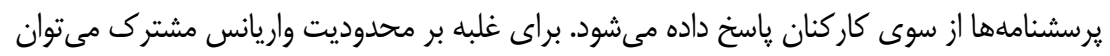
از سنجشهاى •وس درجهاى يا سلهوسازى براى تعميميذيرى بهتر دادهها استفاده كرد. محدوديت

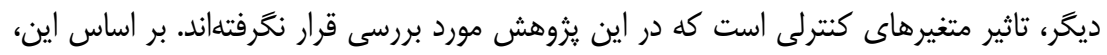

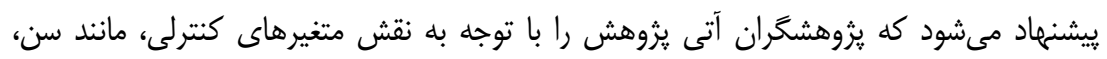

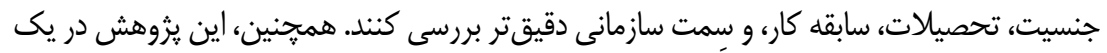

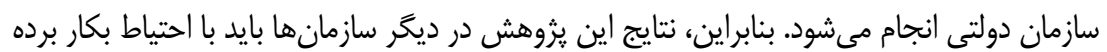

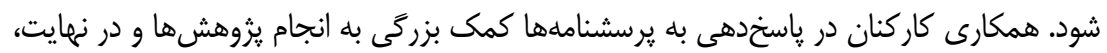

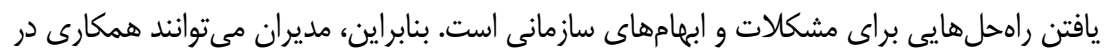

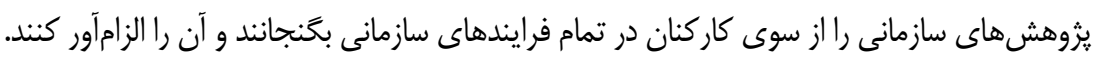




\section{منابع}

\section{الف) فارسى}

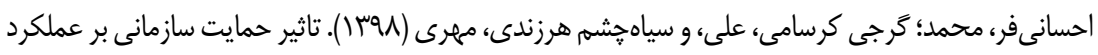

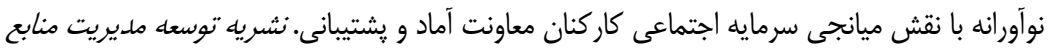

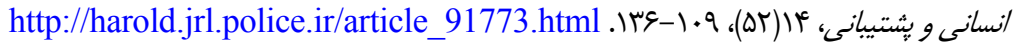

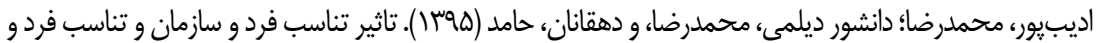

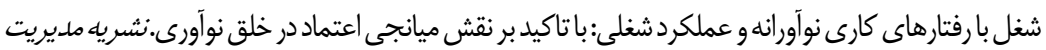

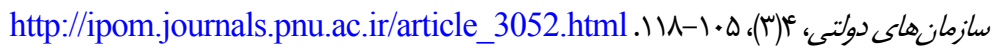

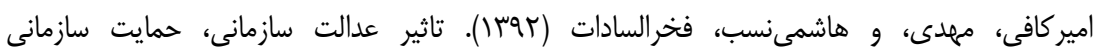

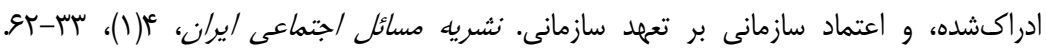
http://jspi.khu.ac.ir/article-1-295-fa.html

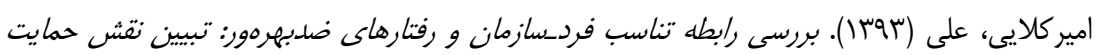

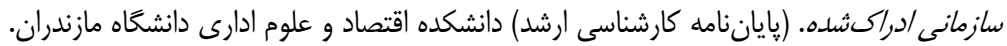

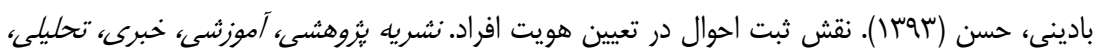

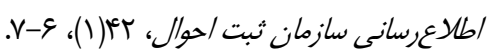

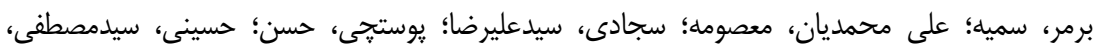

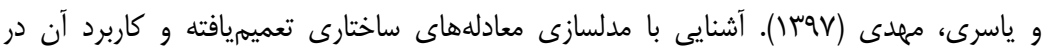

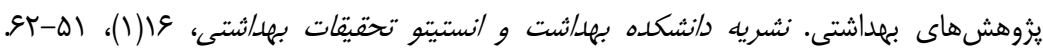
http://sjsph.tums.ac.ir/article-1-5624-fa.html شيرى، اردشير؛ دهقانى سلطانى، مهدى؛ نثارى، طاهره، و فارسىزاده، حسين (هوسا). نقش اعتماد به

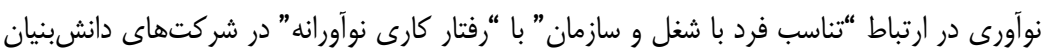

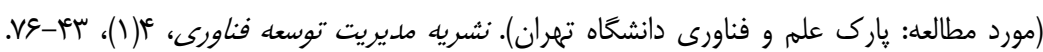
https://dx.doi.org/10.22104/jtdm.2017.475

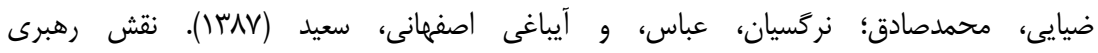

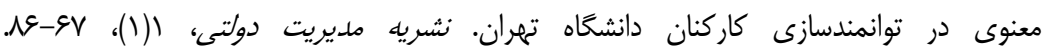
https://jipa.ut.ac.ir/article_27940.html عابدى جعفرى، حسن، و رستگار، عباسعلى (عرىا). ظهور معنويت در سازمانها، مفاهيه، تعاريف،

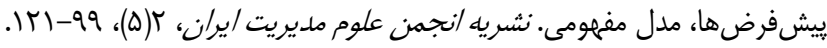

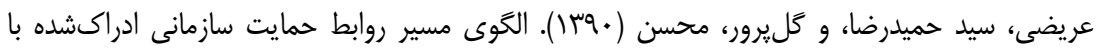

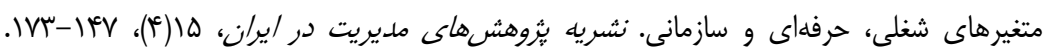
http://mri.modares.ac.ir/article-19-5676-fa.html فقيه آرام، بتول، و خادمى، محسن (عهس ا). رابطه حمايت سازمانى و جوّ سازمانى نوآورانه با اشتياق شغلى

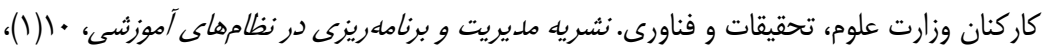




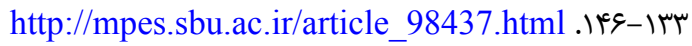

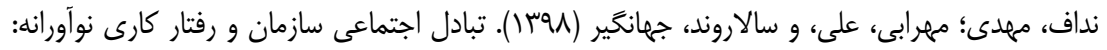

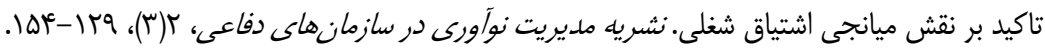

https://dx.doi.org/10.22034/qjimdo.2019.101888

Afsar, B., \& Rehman, M. (2015). The Relationship between Workplace Spirituality and Innovative Work Behavior: The Mediating Role of Perceived Person-Organization Fit. Journal of Management, Spirituality \& Religion, 12(4), 329-353. https://doi.org/10.1080/14766086.2015.1060515

Afsar, B., Badir, Y., \& Kiani, U. S. (2016). Linking Spiritual Leadership and Employee Pro-Environmental Behavior: The Influence of Workplace Spirituality, Intrinsic Motivation, and Environmental Passion. Journal of Environmental Psychology, 45(1), 79-88. https://doi.org/10.1016/j.jenvp.2015.11.011

Akhtar, M. W., Syed, F., Husnain, M., \& Naseer, S. (2019). Person-Organization Fit and Innovative Work Behavior: The Mediating Role of Percei ved Organizational Support, Affective Commitment and Trust. Pakistan Journal of Commerce and Social Sciences (PJCSS), 13(2), 311-333.

Argyris, C. (1958). The Organization-What Makes It Healthy. Harvard Business Review, 36(6), 107-116.

Borchers, B. J. (2006). Workplace Environment Fit, Commitment, and Job Satisfaction in a Nonprofit Association. (Doctor of Philosophy). Walden University,

De Jong, J. P., \& Den Hartog, D. N. (2007). How Leaders Influence Employees' Innovative Behaviour. European Journal of Innovation Management, 10(1), 41-64. https://doi.org/10.1108/14601060710720546

De Jong, J., \& Den Hartog, D. (2010). Measuring Innovative Work Behaviour. Creativity and Innovation Management, 19(1), 23-36. https://doi.org/10.1111/j.1467-8691.2010.00547.x

DeConinck, J. B. (2010). The Effect of Organizational Justice, Perceived Organizational Support, and Perceived Supervisor Support on Marketing Employees' Level of Trust. Journal of Business Research, 63(12), 13491355. https://doi.org/10.1016/j.jbusres.2010.01.003

Doğru, Ç. (2018). The Relationship between Perceived Support and Innovative Behavior: Analyzing the Mediating Role of Work Engagement. İşletme Araştırmaları Dergisi, 10(2), 384-402.

Duverger, P. (2012). Using Dissatisfied Customers as a Source for Innovative 
Service Ideas. Journal of Hospitality \& Tourism Research, 36(4), 537-563. https://doi.org/10.1177/1096348011413591

Eisenberger, R., Armeli, S., Rexwinkel, B., Lynch, P. D., \& Rhoades, L. (2001). Reciprocation of Perceived Organizational Support. Journal of Applied Psychology, 86(1), 42-53. https://doi.org/10.1037/0021-9010.86.1.42

Eisenberger, R., Huntington, R., Hutchison, S., \& Sowa, D. (1986). Perceived Organizational Support. Journal of Applied Psychology, 71(3), 500-507. https://doi.org/10.1037/0021-9010.71.3.500

Gilson, L. L., \& Shalley, C. E. (2004). A Little Creativity Goes a Long Way: An Examination of Teams' Engagement in Creative Processes. Journal of Management, 30(4), 453-470. https://doi.org/10.1016/j.jm.2003.07.001

Gregory, B. T., Albritton, M. D., \& Osmonbekov, T. (2010). The Mediating Role of Psychological Empowerment on the Relationships between P-O Fit, Job Satisfaction, and In-Role Performance. Journal of Business and Psychology, 25(4), 639-647. https://doi.org/10.1007/s10869-010-9156-7

Gupta, M., Kumar, V., \& Singh, M. (2014). Creating Satisfied Employees Through Workplace Spirituality: A Study of the Private Insurance Sector in Punjab (India). Journal of Business Ethics, 122(1), 79-88. https://doi.org/10.1007/s10551-013-1756-5

Kanter, R. M. (1979). Power Failure in Management Circuits. Classics of Organization Theory, 57(4), 342-351.

Karatepe, O. M. (2012). Perceived Organizational Support, Career Satisfaction, and Performance Outcomes. International Journal of Contemporary Hospitality Management, 24(5), 735-752. https://doi.org/10.1108/09596111211237273

Kim, T. T., \& Lee, G. (2013). Hospitality Employee Knowledge-Sharing Behaviors in the Relationship between Goal Orientations and Service Innovative Behavior. International Journal of Hospitality Management, 34(1), 324-337. https://doi.org/10.1016/j.ijhm.2013.04.009

King-Kauanui, S., Thomas, K. D., \& Waters, G. R. (2005). Entrepreneurship and Spirituality: Integration of Spirituality into the Workplace. Journal of Management, Spirituality \& Religion, 2(2), 255-274. https://doi.org/10.1080/14766080509518582

Kristof-Brown, A. L., Zimmerman, R. D., \& Johnson, E. C. (2005). Consequences OF Individuals'Fit at Work: A MetaAnalysis of Person-Job, Person-Organization, Person-Group, and Person-Supervisor Fit. Personnel Psychology, 58(2), 281-342. https://doi.org/10.1111/j.1744-6570.2005.00672.x

Lee, S., Lovelace, K. J., \& Manz, C. C. (2014). Serving With Spirit: An 
Integrative Model of Workplace Spirituality within Service Organizations. Journal of Management, Spirituality \& Religion, 11(1), 45-64. https://doi.org/10.1080/14766086.2013.801023

Mitroff, I. I. (2003). Do Not Promote Religion Under the Guise of Spirituality. Organization, 10(2),375-382.https://doi.org/10.1177/1350508403010002011

Mura, M., Lettieri, E., Radaelli, G., \& Spiller, N. (2013). Promoting Professionals' Innovative Behaviour through Knowledge Sharing: The Moderating Role of Social Capital. Journal of Knowledge Management, 17(4), 527-544. https://doi.org/10.1108/JKM-03-2013-0105

Pandey, A., Gupta, V., \& Gupta, R. K. (2019). Spirituality and Innovative Behaviour in Teams: Examining the Mediating Role of Team Learning. IIMB Management Review, 31(2), 116-126. https://doi.org/10.1016/j.iimb.2019.03.013 Quatro, S. A. (2004). New Age or Age Old: Classical Management Theory and Traditional Organized Religion as Underpinnings of the Contemporary Organizational Spirituality Movement. Human Resource Development Review, 3(3), 228-249. https://doi.org/10.1177/1534484304267830

Ranasinghe, V. R., \& Samarasinghe, S. M. (2019). The Effect of Workplace Spirituality on Innovative Work Behavior. International Business Research, 12(12), 29-38.

Ranji Jafroodi, N., \& Nasrollahi Moghaddam, P. (2020). The Impact of Perceived Social Responsibility on Emotional Commitment Based on the Mediating Role of Employee-Organization Compatibility, Organizational Identity and Perceived Organizational Support. Quarterly Journal for Management and Development Process, 33(3), 71-93. http://jmdp.ir/article-1-3829-fa.html

Rego, A., \& e Cunha, M. P. (2008). Workplace Spirituality and Organizational Commitment: An Empirical Study. Journal of Organizational Change Management, 21(1), 53-75. https://doi.org/10.1108/09534810810847039

Rhoades, L., \& Eisenberger, R. (2002). Perceived Organizational Support: A Review of the Literature. Journal of Applied Psychology, 87(4), 698-714. https://doi.org/10.1037/0021-9010.87.4.698

Saks, A. M. (2011). Workplace Spirituality and Employee Engagement. Journal of Management, Spirituality \& Religion, 8(4), 317-340. https://doi.org/10.1080/14766086.2011.630170

Schneider, B. (1987). The People Make the Place. Personnel Psychology, 40(3), 437-453. https://doi.org/10.1111/j.1744-6570.1987.tb00609.x

Scott, S. G., \& Bruce, R. A. (1994). Determinants of Innovative Behavior: A Path Model of Individual Innovation in the Workplace. Academy of Management Journal, 37(3), 580-607. https://doi.org/10.5465/256701 
Silverthorne, C. (2004). The Impact of Organizational Culture and PersonOrganization Fit on Organizational Commitment and Job Satisfaction in Taiwan. Leadership \& Organization Development Journal, 25(7), 592-599. https://doi.org/10.1108/01437730410561477

Simmons, J. F. (2014). Person-Organizational Fit and Perceived Organizational Support Effects on Job Outcomes. (Doctor of Philosophy). Walden University.

Sulaiman, M., Ragheb, M. A., \& Wahba, M. (2019). Perceived Organization Support Role in Creating an Innovative Work Behavior. Open Access Library Journal, 6(5), 1-14.

Susilo, H. (2019). Improving Innovative Work Behavior and Organizational Performance through Workplace Spirituality and Perceived Organizational Support. Paper Presented at the Annual International Conference of Business and Public Administration. https://doi.org/10.2991/aicobpa-18.2019.24

Suwanti, S., Udin, U., \& Widodo, W. (2018). Person-Organization Fit, Person-Job Fit, and Innovative Work Behavior: The Role of Organizational Citizenship Behavior. European Research Studies Journal, 21(3), 389-402. Taheri Goodarzi, H., \& Norouzi, N. (2019). The Impact of Career Adaptability on Career Plateau: The Mediating Role of Person-Job Fit and PersonOrganization Fit. Quarterly Journal for Management and Development Process, 32(3), 3-26. http://jmdp.ir/article-1-3578-fa.html

Verquer, M. L., Beehr, T. A., \& Wagner, S. H. (2003). A Meta-Analysis of Relations between Person-Organization Fit and Work Attitudes. Journal of Vocational Behavior, 63(3), 473-489. https://doi.org/10.1016/S0001-8791(02)00036-2

Vilela, B. B., González, J. A. V., \& Ferrín, P. F. (2008). Person-Organization Fit, OCB and Performance Appraisal: Evidence from Matched SupervisorSalesperson Data Set in a Spanish Context. Industrial Marketing Management, 37(8), 1005-1019. https://doi.org/10.1016/j.indmarman.2007.11.004

Werbel, J. D., \& DeMarie, S. M. (2005). Aligning Strategic Human Resource Management and Person-Environment Fit. Human Resource Management Review, 15(4), 247-262. https://doi.org/10.1016/j.hrmr.2005.10.001

West, M. A., \& Farr, J. L. (1989). Innovation at Work: Psychological Perspectives. Social Behaviour, 4(1), 15-30.

Zaman, Q., Qureshi, F. A., \& Butt, M. (2020). Mediating Effect of Perceived Organizational Support on the Relationship between Leader-Member Exchange and the Innovation Work Behavior of Nursing Employees: A Social Exchange Perspective. Business Innovation and Entrepreneurship Journal, 2(1), 67-76. https://doi.org/10.35899/biej.v2i1.63 